\title{
Assessment of the Usability and Accuracy of Two-Diode Models for Photovoltaic Modules
}

\author{
Vincenzo Franzitta, Aldo Orioli * and Alessandra Di Gangi \\ Dipartimento di Energia, Ingegneria dell'Informazione e Modelli Matematici (DEIM), \\ Università degli Studi di Palermo, Viale delle Scienze Edificio 9, 90128 Palermo, Italy; \\ vincenzo.franzitta@unipa.it (V.F.); alessandradigangi@dream.unipa.it (A.D.G.) \\ * Correspondence: orioli@dream.unipa.it or aldo.orioli@unipa.it; Tel.: +39-912-386-1905; Fax: +39-9148-4425
}

Academic Editor: Senthilarasu Sundaram

Received: 4 January 2017; Accepted: 18 April 2017; Published: 20 April 2017

\begin{abstract}
Many diode-based equivalent circuits for simulating the electrical behaviour of photovoltaic (PV) cells and panels are reported in the scientific literature. Two-diode equivalent circuits, which require more complex procedures to calculate the seven model parameters, are less numerous. The model parameters are generally calculated using the data extracted from the datasheets issued by the PV panel manufactures and adopting simplifying hypotheses and numerical solving techniques. A criterion for rating both the usability and accuracy of two-diode models is proposed in this paper with the aim of supporting researchers and designers, working in the area of PV systems, to select and use a model that may be fit for purpose. The criterion adopts a three-level rating scale that considers the ease of finding the data used by the analytical procedure, the simplicity of the mathematical tools needed to perform calculations and the accuracy achieved in calculating the current and power. The analytical procedures, the simplifying hypotheses and the operative steps to calculate the parameters of the most famous two-diode equivalent circuits are exhaustively described in this paper. The accuracy of the models is tested by comparing the characteristics issued by the PV panel manufacturers with the current-voltage (I-V) curves, at constant solar irradiance and/or cell temperature, calculated with the analysed models with. The results of the study show that the two-diode models recently proposed reach accuracies that are comparable with the values derived from the one-diode models.
\end{abstract}

Keywords: photovoltaic modules; two-diode equivalent circuit; $I-V$ characteristics; solar energy

\section{Introduction}

Numerous analytical procedures for determining the model parameters of one and two diode equivalent circuits have been proposed [1-45]. These models use a set of analytical relations derived from the performance data, usually provided by manufacturers, and arranged in an equation system whose solution is often made easier through the adoption of some simplifying hypotheses and/or iterative methods. Some authors have also faced the problem of the identification of the model parameters by means of alternative methods such as genetic algorithms, cluster analysis, Padè approximants, harmony search-based algorithms, Lambert $W$-function, reduced forms, evolutionary algorithms, artificial neural networks and small perturbations around the operating point [46-59].

The paper is organised along the lines of a previous study regarding simplified one-diode models for photovoltaic (PV) modules [60]. The analytical procedures to extract the two-diode equivalent circuit parameters and the hypotheses assumed to simplify the mathematical computations are described. In order to verify the effectiveness and accuracy of the analysed models, the $I-V$ characteristics calculated with the proposed procedures, are compared to the performance curves issued by the manufacturers of some silicon PV modules. The paper is organised as follows: Section 2 
presents the seven-parameter two-diode model and the effects of the diode saturation currents, series and shunt resistances, on the shape of the I-V curves. The most famous two-diode models are described in Section 3, along with the hypotheses adopted and the operative steps to obtain the model parameters. In Section 4 the analysed two-diode models are used to calculate the $I-V$ characteristics of some PV modules and the results of the comparison with the performance curves issued by manufacturers are presented. The detailed descriptions of the mathematical procedures used to get the explicit or implicit expressions necessary to evaluate the model parameters are listed in the Appendix A.

\section{The Two-Diode Equivalent Circuit}

In the two-diode model, which is depicted in Figure 1, a second diode is added to consider the effect of the carrier recombination in the depletion region. The equivalent circuit contains seven parameters, which are photocurrent $I_{L}$, diode reverse saturation currents $I_{01}$ and $I_{02}$, series resistance $R_{s}$, shunt resistance $R_{s h}$, and diode quality factors $n_{1}=a_{1} N_{c s} k / q$ and $n_{2}=a_{2} N_{c s} k / q$ in which $a_{1}$ and $a_{2}$ are the diode shape factors, $N_{c S}$ is the number of cells of the panel that are connected in series, $q$ is the electron charge $\left(1.602 \times 10^{-19} \mathrm{C}\right)$ and $k$ is the Boltzmann constant $\left(1.381 \times 10^{-23} \mathrm{~J} / \mathrm{K}\right)$.

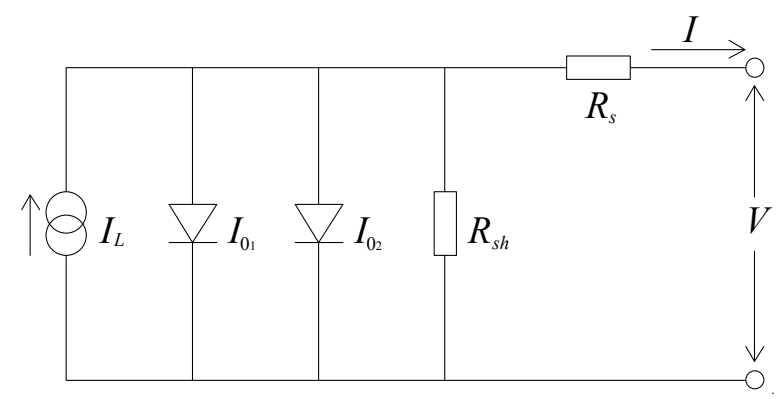

Figure 1. Two-diode equivalent circuit for a PV panel.

The two-diode model is described by the well-known equation:

$$
I=I_{L}-I_{01}\left(e^{\frac{V+I R_{s}}{n_{1} T}}-1\right)-I_{02}\left(e^{\frac{V+I R_{s}}{n_{2} T}}-1\right)-\frac{V+I R_{S}}{R_{s h}}
$$

where, following the traditional theory, photocurrent $I_{L}$ depends on the solar irradiance and diode currents $I_{01}$ and $I_{02}$ are affected by the cell temperature. Due to the large number of parameters used, the two-diode model is supposed to be fit to adequately represent any $I-V$ characteristic, regardless of the shape peculiarities due to the different production technology of the simulated PV panels. Actually, because the production technology affects the shape of the $I-V$ characteristics, crystalline silicon and thin-film PV cells and modules have very different performance curves. As depicted in Figure 2, in which the range-scaled $I-V$ characteristics at the standard rating conditions (SRC)-irradiance $G_{r e f}=1000 \mathrm{~W} / \mathrm{m}^{2}$, cell temperature $T_{\text {ref }}=25^{\circ} \mathrm{C}$ and average solar spectrum at AM 1.5-of some types of PV modules are compared, the crystalline PV modules show an $I-V$ characteristic with a very sharp bent, whereas the thin-film modules are generally characterized by smoother $I-V$ curves.

Different techniques are used to make crystalline and thin-film PV modules. Mono-crystalline and polycrystalline PV cells are made of wafers sawed from silicon ingots obtained by means of a method of crystal growth or from molten silicon, which is carefully cooled and solidified. Conversely, the material of thin-film PV modules is deposited onto a substrate, or onto previously deposited layers, by means of various chemical and/or physical methods. The slopes of the $I-V$ curves of Figure 2 near the open circuit point $(0,1)$ confirm the fact that the high quality silicon slabs of polycrystalline modules dissipate less energy than the materials used to make amorphous or triple junction PV panels. The values of $R_{s}, R_{s h}, n_{1}, n_{2}, I_{01}$ and $I_{02}$ variously affect the $I-V$ characteristic of the PV panel [61]. 
The series and shunt resistances, whose effects are shown in Figures 3 and 4, take account of dissipative phenomena and parasitic currents within the PV panel.

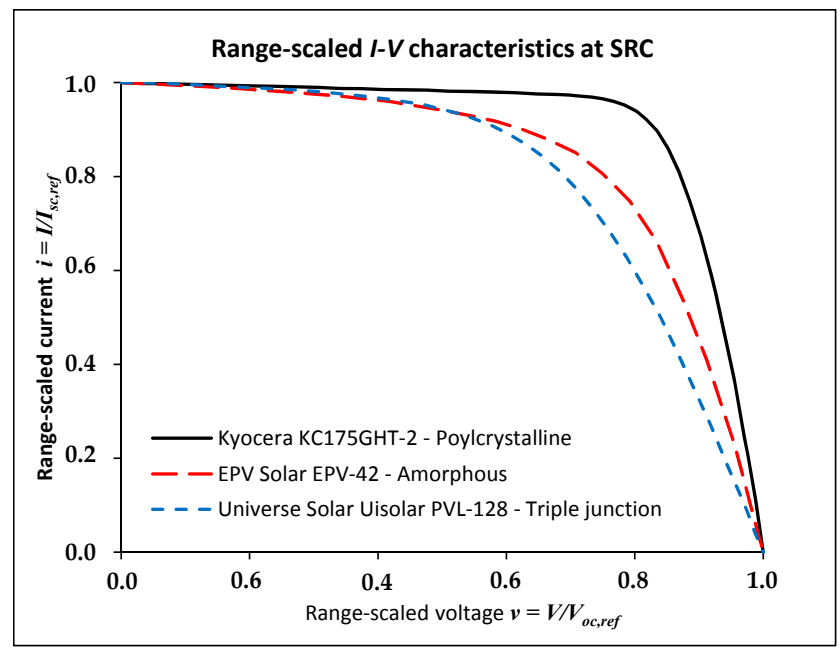

Figure 2. Range-scaled $I-V$ characteristics of crystalline and thin-film PV panels at the SRC.

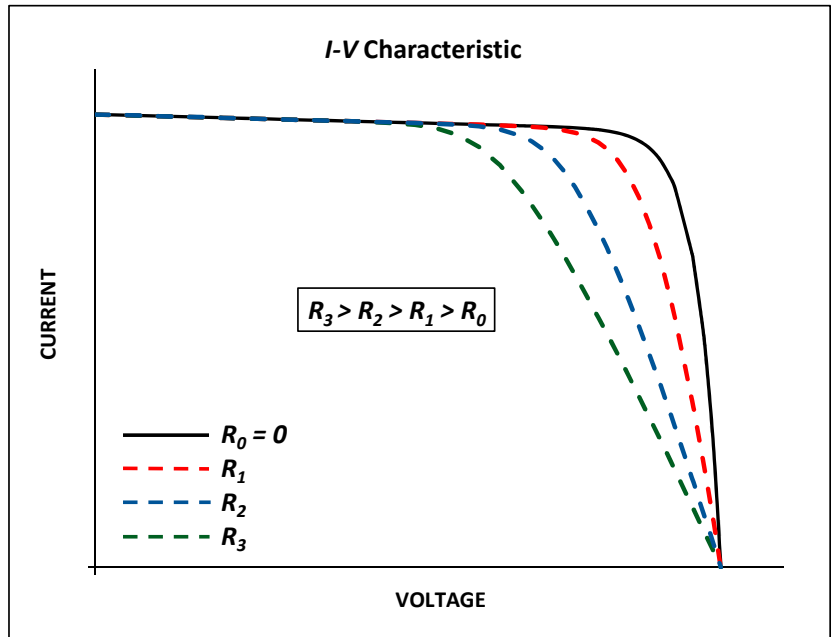

Figure 3. Effects of the series resistance on the $I-V$ characteristic.

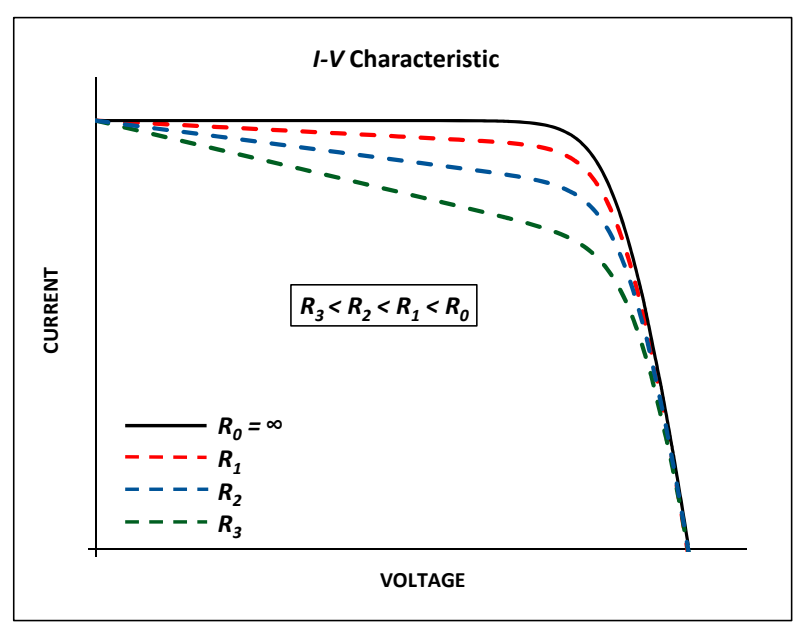

Figure 4. Effects of the shunt resistance on the $I-V$ characteristic. 
The series resistance impacts the shape of the $I-V$ characteristic close and beyond the maximum power point (MPP), which is approximately set on the "knee" of the curve; the shunt resistance modifies the $I-V$ curve for values of the voltage that are smaller than the MPP voltage. As depicted in Figure 5, the presence of the second diode saturation current modifies the curvature of the $I-V$ characteristic close the MPP.

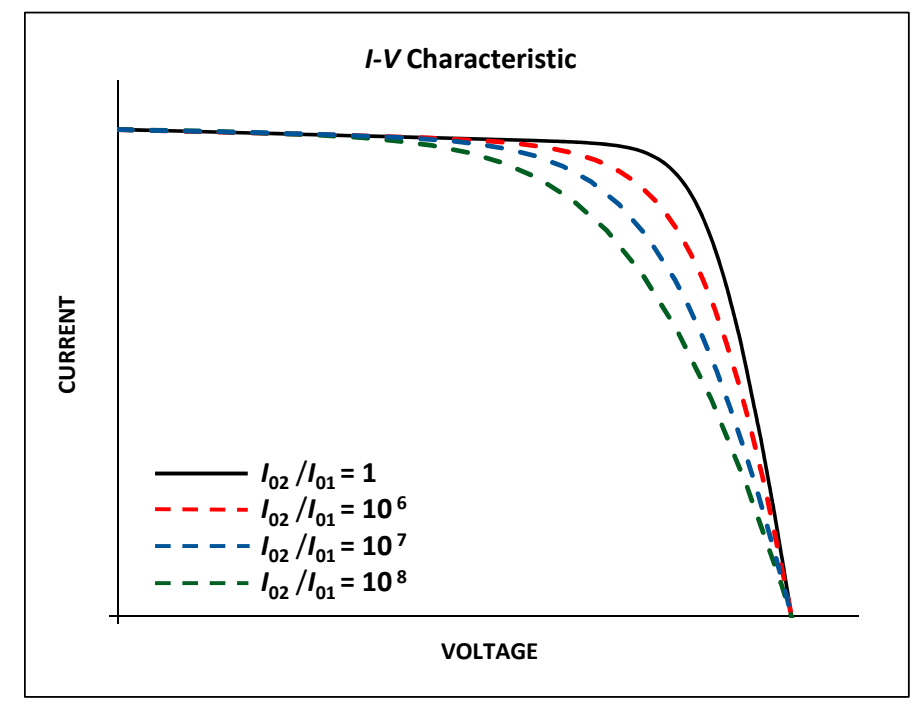

Figure 5. Effects of the saturation currents on the $I-V$ characteristic.

At a constant value of the solar irradiance, the position of the MPP is lowered if $R_{S}$ is increased, $R_{s h}$ is reduced and $I_{02}$ is much greater than $I_{01}$. As a consequence, a small value of the filling factor is reached. Such a peculiarity characterizes thin-film PV modules that, for this reason, usually result less energy efficient than the crystalline silicon PV panels.

The parameters of the two-diode models are generally calculated using the following data which are usually available in the manufacturer datasheets:

- $\quad$ open circuit voltage $V_{o c, r e f}$ and short circuit current $I_{s c, r e f}$ at the standard reporting conditions (SRC);

- $\quad$ voltage $V_{m p, r e f}$ and current $I_{m p, r e f}$ at the MPP at the SRC;

- open circuit voltage temperature coefficient $\mu_{V, o c}$ and short circuit current temperature coefficient $\mu_{I, s c}$.

Some procedures also require the number of series connected PV cells, or the derivative of the $I-V$ curve calculated at the short circuit and open circuit points. Due to the presence of current $I$ in both terms of transcendent Equation (1), exact mathematical methods cannot be used to solve the seven-equation system, which is necessary to calculate the model parameters. Both approximate forms of the equations and numerical solving techniques have been used to solve the problem.

\section{Usability of the Two-Diode Models}

Some procedures to calculate the parameters of the two-diode model have been proposed. Early models for PV cells and panels, which were presented by Chan et al. [40], Enebish et al. [41] and Hovinen [42], were conceived to calculate the $I-V$ characteristic at certain values of solar irradiance and cell temperature, which can be the SRC or any others. Some models, able to give a complete representation of the performance curves for any condition different from the SRC, were proposed by Ishaque et al. [43], Gupta et al. [44] and Hejri et al. [45]. Such recent models face the complex problem of the analytical solution of the involved equations by assuming some simplifying hypotheses and/or reducing the number of independent parameters. 


\subsection{Chan and Phang Model}

Chan et al. [40] used Equation (1) to represent the $I-V$ characteristic of a PV solar cell at the SRC. To make the calculated curve coincide with an experimental characteristic, the following information was considered:

(1) shape factor $a_{1}=1$;

(2) shape factor $a_{2}=2$;

(3) short circuit point $\left(I=I_{s c, r e f} ; V=0\right)$;

(4) open circuit point $\left(I=0 ; V=V_{o c, r e f}\right)$;

(5) $\operatorname{MPP}\left(I=I_{m p, r e f} ; V=V_{m p, r e f}\right)$;

(6) derivative of current at the short circuit point $\left(\partial I / \partial V=-1 / R_{\text {sho }}\right.$ at $\left.I=I_{s c, r e f} ; V=0\right)$;

(7) derivative of current at the open circuit point $\left(\partial I / \partial V=-1 / R_{s o}\right.$ at $\left.I=0 ; V=V_{o c, r e f}\right)$.

In order to simplify the evaluation of the model parameters, the following hypotheses are assumed:

$$
\begin{gathered}
e^{\frac{V_{o c, r e f}}{n T_{r e f}}}>>e^{\frac{I_{s c, r e f} R_{s}}{n T_{r e f}}}, \quad e^{\frac{V_{o c, r e f}}{2 n T_{r e f}}}>>e^{\frac{I_{s c, r e f} R_{s}}{2 n T_{r e f}}}, \quad R_{s h}>>R_{s}, \quad R_{\text {sho }}>>R_{s} \\
\frac{I_{01, r e f}}{n T_{\text {ref }}} e^{\frac{I_{s c, r e f} R_{s}}{n T_{r e f}}}<<\frac{1}{R_{\text {sho }}}, \quad \frac{I_{02, r e f}}{2 n T_{\text {ref }}} e^{\frac{I_{s c, r e f} R_{s}}{2 n T_{r e f}}}<<\frac{1}{R_{\text {sho }}}, \quad I_{s c, \text { ref }} R_{s} \quad<<V_{\text {oc, ref }}
\end{gathered}
$$

Moreover, as described in the Appendix A, some exponential terms containing the parameter $R_{s}$ are substituted with their respective power series. Using the first two terms, or the first three terms, of the power series, the equation that describes the derivative of current at the open circuit point can be approximated with a quadratic form, or a cubic form, respectively. Depending on the use of the quadratic or cubic form, two models were presented, which in this paper are named Chan et al. n.1 and Chan et al. n.2 models, respectively. The model parameters can be calculated with the explicit equations listed in the Appendix A. A new set of model parameters should be calculated for any generic value of solar irradiance and/or cell temperature.

\subsection{Enebish, Agchbayar, Dorjkhand, Baatar and Ylemj Model}

The determination of a solar cell characteristic at the SRC was presented by Enebish et al. [41] who proposed a double diode model based on the following information:

(1) shape factor $a_{1}=1$;

(2) shape factor $a_{2}=2$;

(3) short circuit point $\left(I=I_{s c, r e f} ; V=0\right)$;

(4) open circuit point $\left(I=0 ; V=V_{o c, r e f}\right)$;

(5) derivative of current at the short circuit point $\left(\partial I / \partial V=-1 / R_{s h o}\right.$ at $\left.I=I_{s c, r e f} ; V=0\right)$;

(6) derivative of current at the open circuit point $\left(\partial I / \partial V=-1 / R_{s o}\right.$ at $\left.I=0 ; V=V_{o c, r e f}\right)$;

(7) derivative of power at the $\operatorname{MPP}\left(\partial(V I) / \partial V=0 ; V=V_{m p, r e f}\right)$.

The above information is used to write an equation system that is solved using the Newton-Raphson technique. Because the convergence of the procedure strongly depends on the initial values of $I_{L, r e f}, I_{01, r e f}, I_{02, r e f}, R_{s}$, and $R_{s h}$, the use of some relations described in the appendix was suggested. The model was only used to calculate the $I-V$ characteristics at the SRC.

\subsection{Hovinen Model}

Hovinen [42] used the following information to calculate the parameters of the two-diode equivalent circuit: 
(1) shape factor $a_{1}=1$;

(2) shape factor $a_{2}=2$;

(3) short circuit point $\left(I=I_{s c, r e f} ; V=0\right)$;

(4) open circuit point $\left(I=0 ; V=V_{o c, r e f}\right)$;

(5) $\operatorname{MPP}\left(I=I_{m p, r e f} ; V=V_{m p, r e f}\right)$;

(6) derivative of current at the short circuit point $\left(\partial I / \partial V=-1 / R_{\text {sho }}\right.$ at $\left.I=I_{s c, r e f} ; V=0\right)$;

(7) derivative of power at the MPP $\left(\partial P / \partial V=0 ; V=V_{m p, r e f}\right)$.

As described in the Appendix A, from the information used, parameters $I_{01, \text { ref }}, I_{02, \text { ref }}, R_{\text {sh }}$, and $I_{L, \text { ref }}$ can be calculated by means of an iterative procedure. Hovinen did not use the model to calculate the $I-V$ characteristics for values of solar irradiance and cell temperature different from the SRC.

\subsection{Ishaque, Salam and Taheri Model}

An improved modelling approach for the two-diode model was proposed by Ishaque et al. [43]. The model is based on the following information:

(1) shape factor $a_{1}=1$;

(2) shape factor $a_{2} \geq 1.2$;

(3) diode current $I_{02}=I_{01}=I_{0}$;

(4) short circuit point $\left(I=I_{s c, \text { ref }} ; V=0\right)$;

(5) open circuit point $\left(I=0 ; V=V_{o c, \text { ref }}\right)$;

(6) $\operatorname{MPP}\left(I=I_{m p, r e f} ; V=V_{m p, r e f}\right)$;

(7) maximum power $\left(P=P_{m p, r e f}\right)$.

Assuming the hypotheses:

$$
e^{\frac{I_{c, \text { ref }} R_{s}}{n T_{r e f}}} \approx 1, \quad e^{\frac{I_{s c, r e f} R_{s}}{(p-1) n T_{r e f}}} \approx 1, \quad \frac{I_{s c, r e f} R_{s}}{R_{s h}} \approx 0
$$

In which $n=a_{1} N_{c s} k / q$ and $p=a_{1}+a_{2}$, photocurrent $I_{L, \text { ref }}$ at the SRC and shunt resistance $R_{s h}$ can be calculated with the iterative procedure described in the Appendix A.

\subsection{Gupta, Tiwari, Fozdar and Chandna Model}

Gupta et al. [44] based on the following information the analytical procedure to calculate the parameters of a two-diode model of photovoltaic modules suitable for the use in simulation studies:

(1) shape factor $a_{1}=1$;

(2) shape factor $a_{2}=1$;

(3) shunt resistance $R_{s h}=\infty$;

(4) fixed value of series resistance $R_{s}$;

(5) short circuit point $\left(I=I_{s c, r e f} ; V=0\right)$;

(6) $\operatorname{MPP}\left(I=I_{m p, r e f} ; V=V_{m p, r e f}\right)$.

The two-diode equation is transformed in the following form:

$$
I=I_{s c, r e f}\left[1-K_{3}\left(e^{\frac{V}{K_{2} V_{o c, r e f}}}-1\right)\left(1+K_{1}\right)\right]
$$

in which coefficients $K_{1}, K_{2}$ and $K_{3}$ are calculated with the equations listed in the Appendix A. 


\subsection{Hejri, Mokhtari, Azizian, Ghandhari and Söder Model}

Hejri et al. [45] proposed a procedure for the extraction of the parameters of the two-diode equivalent model. A set of approximate analytical solutions for the model parameters, which can be used as initial conditions for the numerical solutions based on the Newton-Raphson method, were also proposed. The model is based on the following information:

(1) shape factor $a_{1}=1$;

(2) shape factor $a_{2}=2$;

(3) short circuit point $\left(I=I_{s c, r e f} ; V=0\right)$;

(4) open circuit point $\left(I=0 ; V=V_{o c, r e f}\right)$;

(5) $\operatorname{MPP}\left(I=I_{m p, r e f} ; V=V_{m p, r e f}\right) ;$

(6) derivative of current at the short circuit point $\left(\partial I / \partial V=-1 / R_{\text {sho }}\right.$ at $\left.I=I_{s c, r e f} ; V=0\right)$;

(7) derivative of power at the $\operatorname{MPP}\left(\partial P / \partial V=0 ; V=V_{m p, r e f}\right)$.

Adopting the following hypotheses:

$$
\begin{aligned}
& e^{\frac{V_{o c, \text { ref }}}{n T_{r e f}}}>>e^{\frac{I_{S c, \text { ref }} R_{S}}{n T_{r e f}}}, \quad e^{\frac{V_{o c, r e f}}{2 n T_{\text {ref }}}}>>e^{\frac{I_{S c, \text { ref }} R_{S}}{2 n T_{\text {ref }}}} \\
& \frac{I_{01, \text { ref }}}{n T_{\text {ref }}} e^{\frac{I_{s c \text {, ref }} R_{s}}{n T_{\text {ref }}}}<<\frac{1}{R_{\text {sho }}}, \quad \frac{I_{02, \text { ref }}}{2 n T_{\text {ref }}}<<\frac{1}{R_{\text {sho }}}, \quad R_{s}<<R_{\text {sh }}
\end{aligned}
$$

the model parameters are expressed the equations listed in the appendix, which are solved with the Newton-Raphson method.

\subsection{Summary of the Information Used by the Models}

In order to better appreciate the analogies and differences between the various models, the sets of information, hypotheses and solving techniques, on which the analysed procedures are based, are summarised in in Table 1.

Table 1. Summary of the information and solving techniques used by the analysed models.

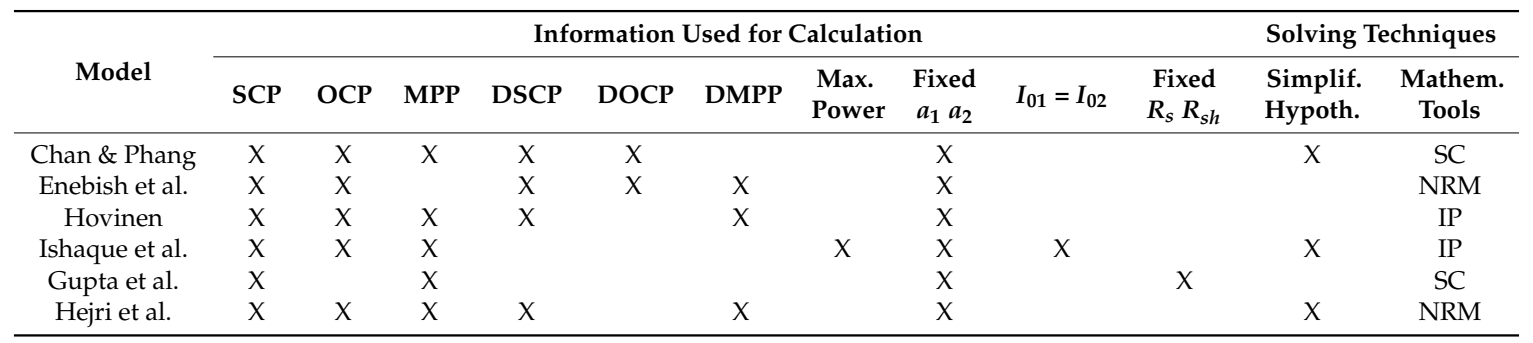

SCP: Short Circuit Point; OCP: Open Circuit Point; MPP: Maximum Power Point; DSCP: Derivative of I at SCP; DOCP: Derivative of $I$ at OCP; DMPP: Derivative of power at MPP; SC: Simple Calculation; IP: Iterative Procedure; NRM: Newton-Raphson Method; Simplif. Hypoth.: Simplifying Hypotheses; Mathem. Tools: Mathematical Tools.

Despite the fact that the same pieces of information are often shared, each model has a particular capability to reproduce the $I-V$ characteristics because of the different mathematical approaches used, which can be very simple or require the implementation of iterative routines and the use of specific mathematical methods, are adopted.

\section{Accuracy of the Simplified Two-Diode Models}

The accuracy of the analysed two-diode models was verified using the various procedures to calculate the $I-V$ characteristics extracted from the manufacturer datasheets. For the sake of brevity, only the $I-V$ characteristics of two PV modules based on different production technologies were used, although such an approach cannot be considered exhaustive because the results are significantly 
affected by the particular shape of the considered $I-V$ curves. In any case, the purpose of this paper is not indicate the best or the worst among the analysed models, but only to evaluate the range of predictable precision in order to calibrate the criterion. The performance data of the simulated PV modules are listed in Table 2.

Table 2. Performance data of the simulated PV panels.

\begin{tabular}{|c|c|c|c|c|c|c|c|c|c|c|}
\hline Panel & Type & $N_{c s}$ & $\begin{array}{l}V_{\text {oc,ref }} \\
\text { (V) }\end{array}$ & $\begin{array}{l}I_{s c, r e f} \\
\text { (A) }\end{array}$ & $\begin{array}{l}V_{m p, r e f} \\
\text { (V) }\end{array}$ & $\begin{array}{c}I_{m p, r e f} \\
(\mathrm{~A})\end{array}$ & $\mu_{V, o c}\left(\mathrm{~V} /{ }^{\circ} \mathrm{C}\right)$ & $\mu_{I, s c}\left(\mathrm{~A} /{ }^{\circ} \mathrm{C}\right)$ & $\begin{array}{l}R_{s o} \\
(\Omega)\end{array}$ & $\begin{array}{l}R_{\text {sho }} \\
(\Omega)\end{array}$ \\
\hline $\begin{array}{c}\text { Kyocera } \\
\text { KD245GH-4FB2 }\end{array}$ & Poly & 60 & 36.90 & 8.91 & 29.80 & 8.23 & $-1.33 \times 10^{-1}$ & $5.35 \times 10^{-3}$ & 0.493 & 120.5 \\
\hline $\begin{array}{l}\text { Sanyo HIT-240 } \\
\text { HDE4 }\end{array}$ & HIT & 60 & 43.60 & 7.37 & 35.50 & 6.77 & $-1.09 \times 10^{-1}$ & $2.21 \times 10^{-3}$ & 0.873 & 3204.6 \\
\hline
\end{tabular}

To evaluate the differences between the calculated and the experimental data, numerous points were extracted from the $I-V$ characteristics issued by the manufacturers, considering both the constant solar irradiance and the constant cell temperature curves. The graphical procedure described in [26] was used to calculate $R_{s h o}$ and $R_{s o}$, which correspond to the reciprocal of slopes of the $I-V$ curve in correspondence of the short circuit and open circuit. Tables 3 and 4 list the values of the parameters obtained using the procedures of the analysed models.

Table 3. Model parameters of Kyocera KD245GH-4FB2 at the SRC.

\begin{tabular}{cccccccc}
\hline Model & $\boldsymbol{I}_{\boldsymbol{L}, \text { ref }}(\mathbf{A})$ & $\boldsymbol{I}_{\mathbf{0 1} \text {,ref }}(\mathbf{A})$ & $\boldsymbol{I}_{\mathbf{0 2 , \text { ref }}}(\mathbf{A})$ & $\boldsymbol{n}_{\mathbf{1}}(\mathbf{V} / \mathbf{K})$ & $\boldsymbol{n}_{\mathbf{2}}(\mathrm{V} / \mathbf{K})$ & $\boldsymbol{R}_{\boldsymbol{s}}(\boldsymbol{\Omega})$ & $\boldsymbol{R}_{\boldsymbol{s h}}(\boldsymbol{\Omega})$ \\
\hline Chan et al. n.1 & 8.9105 & $2.9374 \times 10^{-10}$ & $8.6766 \times 10^{-6}$ & $5.1723 \times 10^{-3}$ & $1.0345 \times 10^{-2}$ & 0.2982 & 120.2800 \\
Chan et al. n.2 & 8.9107 & $3.2868 \times 10^{-10}$ & $3.1907 \times 10^{-6}$ & $5.1723 \times 10^{-3}$ & $1.0345 \times 10^{-2}$ & 0.3083 & 120.2101 \\
Enebish et al. & 8.9335 & $3.5748 \times 10^{-10}$ & $-1.1878 \times 10^{-6}$ & $5.1723 \times 10^{-3}$ & $1.0345 \times 10^{-2}$ & 0.3163 & 120.1507 \\
Hovinen & 8.9334 & $3.5687 \times 10^{-10}$ & $-1.0926 \times 10^{-6}$ & $5.1723 \times 10^{-3}$ & $1.0345 \times 10^{-2}$ & 0.3152 & 120.1540 \\
Ishaque et al. & 8.9304 & $3.6142 \times 10^{-10}$ & $3.6142 \times 10^{-10}$ & $5.1723 \times 10^{-3}$ & $6.2067 \times 10^{-3}$ & 0.2990 & 130.4742 \\
Gupta et al. & 8.9100 & $3.8684 \times 10^{-6}$ & $1.0022 \times 10^{-5}$ & $9.2557 \times 10^{-3}$ & $9.2557 \times 10^{-3}$ & 0.2729 & $\infty$ \\
Hejri et al. & 8.9201 & $3.1573 \times 10^{-10}$ & $6.2900 \times 10^{-6}$ & $5.1723 \times 10^{-3}$ & $1.0345 \times 10^{-2}$ & 0.2819 & 247.5760 \\
\hline
\end{tabular}

Table 4. Model parameters of Sanyo HIT-240 HDE4 at the SRC.

\begin{tabular}{cccccccc}
\hline Model & $\boldsymbol{I}_{\boldsymbol{L}, \text { ref }}(\mathbf{A})$ & $\boldsymbol{I}_{\mathbf{0 1}, \text { ref }} \mathbf{( A )}$ & $\boldsymbol{I}_{\mathbf{0 2}, \text { ref }}(\mathbf{A})$ & $\boldsymbol{n}_{\mathbf{1}}(\mathrm{V} / \mathbf{K})$ & $\boldsymbol{n}_{\mathbf{2}}(\mathbf{V} / \mathbf{K})$ & $\boldsymbol{R}_{\boldsymbol{s}}(\boldsymbol{\Omega})$ & $\boldsymbol{R}_{\boldsymbol{s h}}(\boldsymbol{\Omega})$ \\
\hline Chan et al. n.1 & 7.3699 & $2.3025 \times 10^{-12}$ & $2.1634 \times 10^{-6}$ & $5.1723 \times 10^{-3}$ & $1.0345 \times 10^{-2}$ & 0.6102 & 3235.2782 \\
Chan et al. n.2 & 7.3699 & $3.1880 \times 10^{-12}$ & $9.4282 \times 10^{-7}$ & $5.1723 \times 10^{-3}$ & $1.0345 \times 10^{-2}$ & 0.6432 & 3218.6564 \\
Enebish et al. & 7.3716 & $4.2375 \times 10^{-12}$ & $-5.0268 \times 10^{-7}$ & $5.1723 \times 10^{-3}$ & $1.0345 \times 10^{-2}$ & 0.6730 & 3194.7594 \\
Hovinen & 7.3703 & $7.6662 \times 10^{-13}$ & $4.2806 \times 10^{-6}$ & $5.1723 \times 10^{-3}$ & $1.0345 \times 10^{-2}$ & 0.1358 & 3224.3441 \\
Ishaque et al. & 7.3986 & $3.8791 \times 10^{-12}$ & $3.8791 \times 10^{-12}$ & $5.1723 \times 10^{-3}$ & $6.2067 \times 10^{-3}$ & 0.4720 & 121.8173 \\
Gupta et al. & 7.3700 & $2.8106 \times 10^{-6}$ & $7.2818 \times 10^{-6}$ & $1.0831 \times 10^{-2}$ & $1.0831 \times 10^{-2}$ & 0.3745 & $\infty$ \\
Hejri et al. & 7.3751 & $2.3069 \times 10^{-12}$ & $2.1033 \times 10^{-6}$ & $5.1723 \times 10^{-3}$ & $1.0345 \times 10^{-2}$ & 0.3257 & 468.4439 \\
\hline
\end{tabular}

The values of Tables 3 and 4 were used to calculate the $I-V$ characteristics of the selected PV panels. For the models of Chan et al., Enebish et al. and Hovinen only the $I-V$ curves at the SRC, which are depicted in Figures 6-9, were calculated because the authors did not suggest the way to use their models for values of solar irradiance and cell temperature different from the SRC.

The Enebish et al. model results very accurate for both Kyocera and Sanyo PV panels. The Hovinen model, which is very accurate for the Kyocera PV module, shows a lack of precision for the Sanyo PV panel. The Chan et al. models results less effective close the MPP of the simulated PV modules. In Figures 10 and 11 the $I-V$ curves evaluated at $T=25^{\circ} \mathrm{C}$ using the models of Ishaque et al., Gupta et al. and Hejri et al. are compared with the characteristics issued by manufacturers. Figures 12 and 13 depict the $I-V$ curves evaluated at $G=1000 \mathrm{~W} / \mathrm{m}^{2}$ and the characteristics issued by manufacturers. 


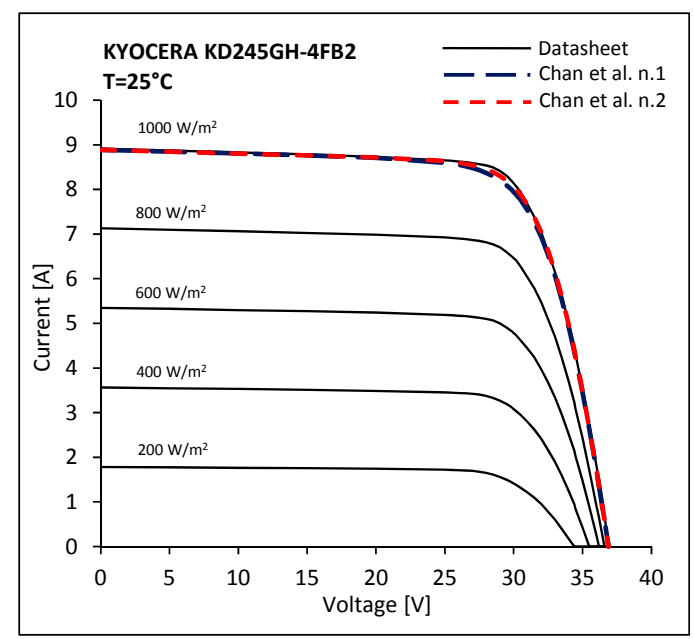

Figure 6. Comparison between the issued $I-V$ characteristics of Kyocera KD245GH-4FB2 at $T=25^{\circ} \mathrm{C}$ and the characteristics calculated by means of the Chan et al. models.

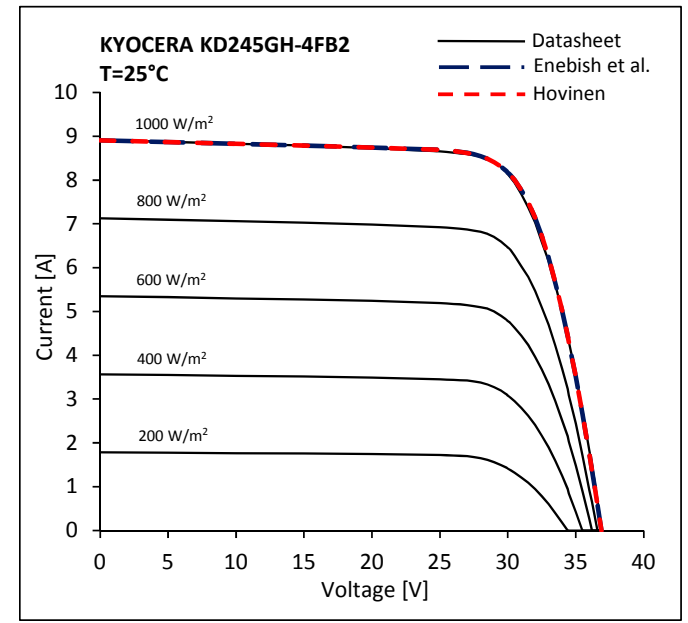

Figure 7. Comparison between the issued $I-V$ characteristics of Kyocera KD245GH-4FB2 at $T=25{ }^{\circ} \mathrm{C}$ and the characteristics calculated by means of the Enebish et al. and the Hovinen models.

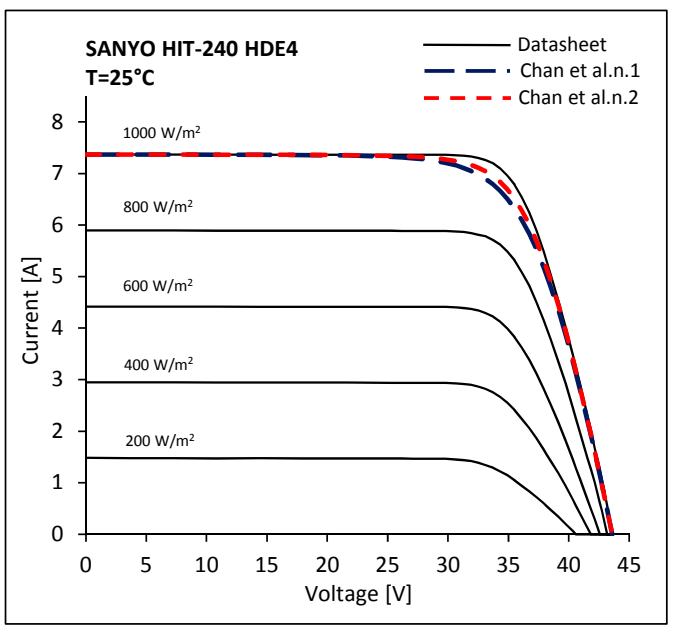

Figure 8. Comparison between the issued $I-V$ characteristics of Sanyo HIT-240 HDE4 at $T=25^{\circ} \mathrm{C}$ and the characteristics calculated by means of Chan et al. models. 


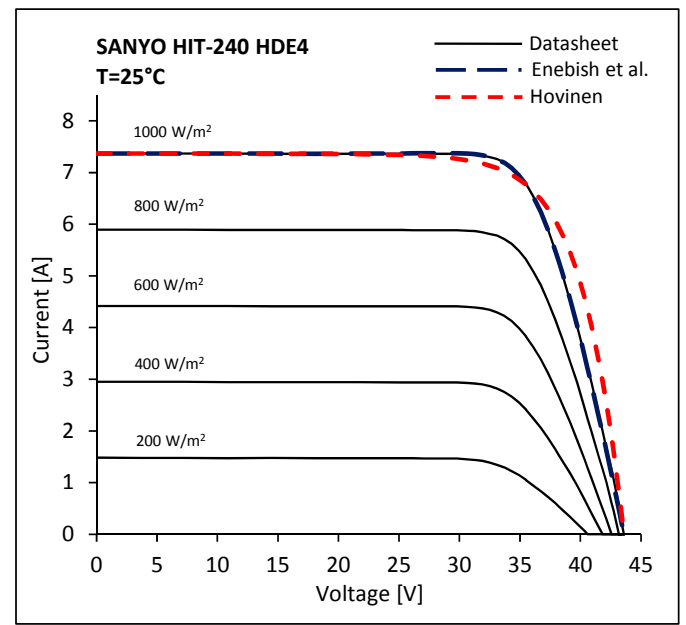

Figure 9. Comparison between the issued $I-V$ characteristics of Sanyo HIT-240 HDE 4 at $T=25^{\circ} \mathrm{C}$ and the characteristics calculated by means of Enebish et al. and the Hovinen models.

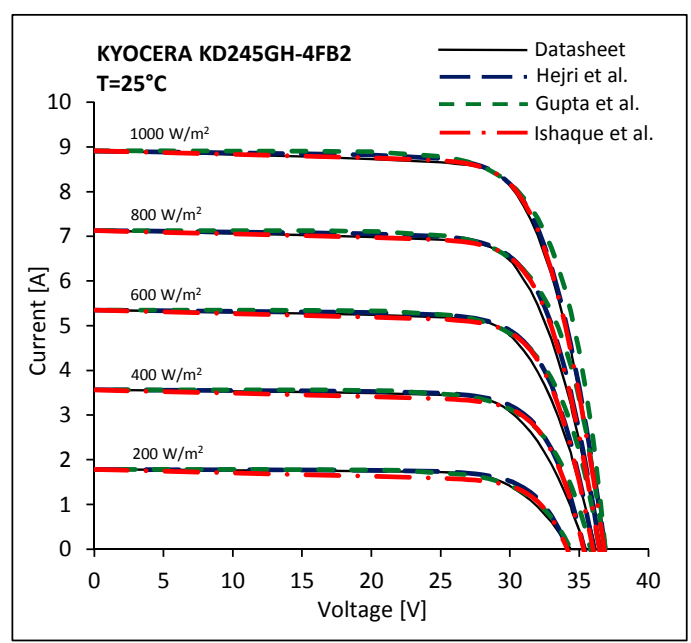

Figure 10. Comparison between the issued $I-V$ characteristics of Kyocera KD245GH-4FB2 at $T=25^{\circ} \mathrm{C}$ and the characteristics calculated by means of the Hejri et al., the Gupta et al. and the Ishaque et al. models.

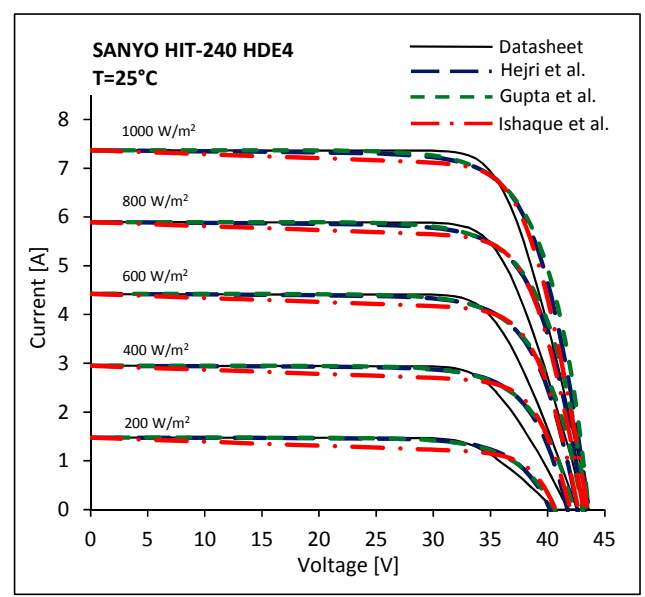

Figure 11. Comparison between the issued $I-V$ characteristics of Sanyo HIT-240 HDE 4 at $T=25^{\circ} \mathrm{C}$ and the characteristics calculated by means of the Hejri et al., the Gupta et al. and the Ishaque et al. models. 


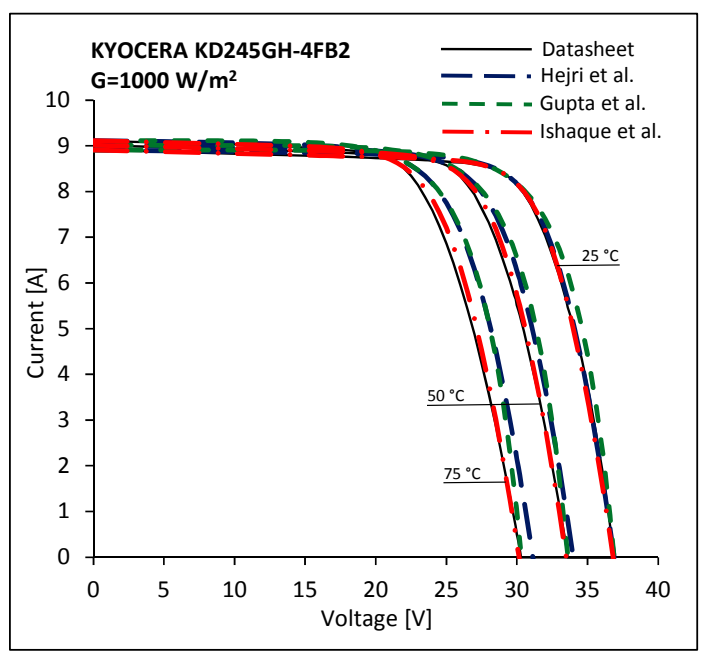

Figure 12. Comparison between the issued $I-V$ characteristics of Kyocera KD245GH-4FB2 at $G=1000 \mathrm{~W} / \mathrm{m}^{2}$ and the characteristics calculated by means of the Hejri et al., the Gupta et al. and the Ishaque et al. models.

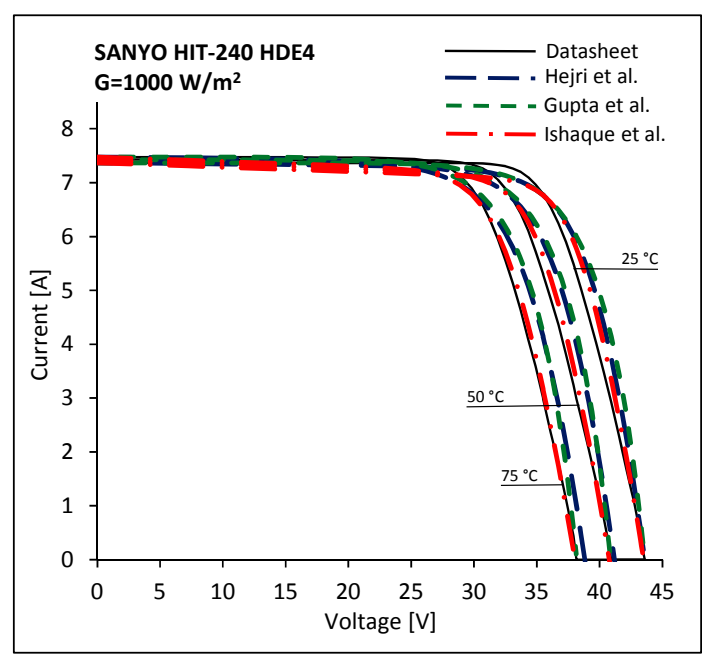

Figure 13. Comparison between the issued $I-V$ characteristics of Sanyo HIT-240 HDE4at $G=1000 \mathrm{~W} / \mathrm{m}^{2}$ and the characteristics calculated by means of the Hejri et al., the Gupta et al. and the Ishaque et al. models.

As observed in Section 3, a value for $R_{S}$ has to be fixed to use the Gupta et al. model. Because no procedure was described by the authors, the needed value of $R_{S}$ is defined imposing that the $I-V$ curve calculated at $G=200 \mathrm{~W} / \mathrm{m}^{2}$ and $T=25^{\circ} \mathrm{C}$ contains the open circuit point extracted from the datasheet characteristics for such values of solar irradiance and silicon temperature.

It can be generally observed in Figures 8-13 that the models result less accurate for values of voltage greater than the MPP voltage. Moreover it seems that the analysed models are more precise if they are used to evaluate the $I-V$ characteristics of the Kyocera PV panel. This may be due to the different shape of the issued $I-V$ curves; actually, the $I-V$ characteristics of the Sanyo PV module show sharper "knees" close to the MPP. The Hejri et al. and the Ishaque et al. models adequately reproduce the issued I- $V$ characteristics of the Kyocera PV panel at the SRC, whereas they are less effective for the Sanyo PV module; the curves calculated with the Gupta et al. model at the SRC are rather different from the issued $I-V$ characteristics. Such occurrences contrast with the fact that the two-diode models should be particularly able to represent the $I-V$ characteristics regardless the shape of the simulated 
curves. In this regard, it must be highlighted that none of the analysed models take full advantage of the seven independent parameters of the two-diode equivalent circuit. It easy to verify that, if constant values for $a_{1}$ and $a_{2}$ are arbitrarily assumed, as was made by all the analysed procedures, the number of independent parameters is reduced from seven to five. Moreover, if it is set $I_{02}=I_{01}$, as it was proposed by Ishaque et al., the number of independent parameters is further lowered to four. Only three independent parameters are used by the Gupta et al. model, who set a fixed ratio of $I_{02}$ to $I_{01}$ and neglected the shunt resistance. A lucky guess of the values of $a_{1}$ and $a_{2}$, and the fact that the system of equations is solved without recourse to mathematical simplifications, are probably the reasons why the Enebish et al. model better reproduce the $I-V$ characteristic of the simulated PV panels.

To quantify the accuracy of the analysed models, the mean absolute difference (MAD) for current and power was calculated with the following expressions:

$$
\begin{gathered}
\operatorname{MAD}(I)=\frac{1}{N} \sum_{j=1}^{N}\left|I_{c a l c, j}-I_{i s s, j}\right| \\
\operatorname{MAD}(P)=\frac{1}{N} \sum_{j=1}^{N}\left|V_{i s s, j} I_{c a l c, j}-V_{i s s, j} I_{i s s, j}\right|
\end{gathered}
$$

in which $V_{i s s, j}$ and $I_{i s s, j}$ are the voltage and current of the $j$-th point extracted from the $I-V$ characteristics issued by manufacturers, $I_{c a l c, j}$ is the value of the current calculated in correspondence of $V_{i s s, j}$ and $N$ is the number of extracted points. Moreover, in order to assess the range of dispersion of the results, also the maximum difference (MD) for current and power was evaluated using the following relations:

$$
\begin{gathered}
\operatorname{MD}(I)=\operatorname{MAX}\left[I_{\text {calc }, j}-I_{i s s, j}\right] \\
\operatorname{MD}(P)=\operatorname{MAX}\left[V_{i s s, j} I_{c a l c, j}-V_{i s s, j} I_{i s s, j}\right]
\end{gathered}
$$

Tables 5 and 6, list the MAD $(I)$ s and MAD $(P)$ s for the Kyocera KD245GH-4FB2 and Sanyo HIT-240

\begin{tabular}{|c|c|c|c|c|c|c|c|}
\hline \multirow{2}{*}{ PV Panel } & \multirow{2}{*}{\multicolumn{2}{|c|}{ Absolute Mean Difference }} & \multicolumn{5}{|c|}{ Irradiance $\left(\mathrm{W} / \mathrm{m}^{2}\right)$} \\
\hline & & & 200 & 400 & 600 & 800 & 1000 \\
\hline \multirow{6}{*}{ Kyocera KD245GH-4FB2 } & \multirow{3}{*}{ Current (A) } & Ishaque et al. model & $\underline{0.078}$ & 0.109 & 0.102 & 0.087 & 0.059 \\
\hline & & Gupta et al. model & $\overline{0.053}$ & 0.174 & 0.238 & 0.299 & $\underline{0.272}$ \\
\hline & & Hejri et al. model & 0.068 & 0.125 & $\overline{0.122}$ & 0.127 & $\overline{0.067}$ \\
\hline & \multirow{3}{*}{ Power $(\mathrm{W})$} & Ishaque et al. model & 2.103 & 3.298 & 3.206 & 2.824 & 1.931 \\
\hline & & Gupta et al. model & $\overline{1.620}$ & 5.648 & 7.857 & 9.931 & $\underline{8.924}$ \\
\hline & & Hejri et al. model & 2.074 & 3.905 & $\overline{3.816}$ & $\overline{4.002}$ & $\overline{2.004}$ \\
\hline \multirow{6}{*}{ Sanyo HIT-240 HDE4 } & \multirow{3}{*}{ Current (A) } & Ishaque et al. model & $\underline{0.171}$ & $\underline{0.281}$ & 0.337 & 0.297 & 0.228 \\
\hline & & Gupta et al. model & $\overline{0.080}$ & 0.224 & $\underline{0.343}$ & $\underline{0.375}$ & $\underline{0.376}$ \\
\hline & & Hejri et al. model & 0.073 & 0.175 & 0.257 & 0.277 & 0.279 \\
\hline & \multirow{3}{*}{ Power $(\mathrm{W})$} & Ishaque et al. model & 5.467 & 9.900 & 12.226 & 10.700 & 8.005 \\
\hline & & Gupta et al. model & $\overline{2.942}$ & 8.614 & 13.477 & 14.897 & 14.892 \\
\hline & & Hejri et al. model & 2.590 & 6.580 & 9.838 & 10.669 & 10.747 \\
\hline
\end{tabular}
HDE4 PV panels.

Table 5. Mean absolute current and power differences between the calculated and the issued $I-V$ characteristics at temperature $T=25^{\circ} \mathrm{C}$.

Considering the solar irradiance variation, for the Kyocera PV panel the smallest MAD $(I)$ s range from 0.053 to $0.109 \mathrm{~A}$; the smallest $\operatorname{MAD}(P)$ s vary from 1.620 to $3.298 \mathrm{~W}$. For the Sanyo PV module the smallest $\mathrm{MAD}(I) \mathrm{s}$ vary between 0.073 and $0.277 \mathrm{~A}$. The smallest $\mathrm{MAD}(P) \mathrm{s}$ are in the range from 2.590 
to $10.669 \mathrm{~W}$. The greatest $\mathrm{MAD}(I) \mathrm{s}$ for the Kyocera PV panel vary from 0.078 to $0.299 \mathrm{~A}$; the greatest $\operatorname{MAD}(P) \mathrm{s}$ range from 2.103 to $9.931 \mathrm{~W}$. For the Sanyo PV module the greatest $\mathrm{MAD}(I) \mathrm{s}$ are contained in the range from 0.171 to $0.376 \mathrm{~A}$. The greatest $\mathrm{MAD}(P) \mathrm{s}$ vary from 5.467 to $14.897 \mathrm{~W}$.

Table 6. Mean absolute current and power differences between the calculated and the issued $I-V$ characteristics at irradiance $G=1000 \mathrm{~W} / \mathrm{m}^{2}$.

\begin{tabular}{|c|c|c|c|c|c|}
\hline \multirow{2}{*}{ PV Panel } & \multirow{2}{*}{\multicolumn{2}{|c|}{ Absolute Mean Difference }} & \multicolumn{3}{|c|}{ Temperature $\left({ }^{\circ} \mathrm{C}\right)$} \\
\hline & & & 25 & 50 & 75 \\
\hline \multirow{6}{*}{ Kyocera KD245GH-4FB2 } & \multirow{3}{*}{ Current (A) } & Ishaque et al. model & 0.059 & 0.085 & 0.124 \\
\hline & & Gupta et al. model & $\underline{0.272}$ & 0.315 & 0.428 \\
\hline & & Hejri et al. model & $\overline{0.067}$ & $\underline{0.338}$ & $\underline{0.669}$ \\
\hline & \multirow{3}{*}{ Power $(\mathrm{W})$} & Ishaque et al. model & 1.931 & 2.383 & 3.228 \\
\hline & & Gupta et al. model & 8.924 & 8.730 & 10.737 \\
\hline & & Hejri et al. model & $\overline{2.004}$ & $\underline{9.979}$ & $\underline{19.517}$ \\
\hline \multirow{6}{*}{ Sanyo HIT-240 HDE4 } & \multirow{3}{*}{ Current (A) } & Ishaque et al. model & 0.228 & 0.193 & 0.143 \\
\hline & & Gupta et al. model & $\underline{0.376}$ & 0.366 & 0.369 \\
\hline & & Hejri et al. model & $\overline{0.279}$ & $\overline{0.362}$ & $\underline{0.478}$ \\
\hline & \multirow{3}{*}{ Power $(\mathrm{W})$} & Ishaque et al. model & 8.005 & 6.232 & 4.216 \\
\hline & & Gupta et al. model & $\underline{14.892}$ & $\underline{13.513}$ & 12.655 \\
\hline & & Hejri et al. model & 10.747 & 13.195 & $\underline{16.587}$ \\
\hline
\end{tabular}

At constant solar irradiance, the smallest $\operatorname{MAD}(I)$ s for the Kyocera PV panel range from 0.059 to $0.124 \mathrm{~A} \mathrm{MD}(I) \mathrm{s}$; the smallest $\mathrm{MAD}(P) \mathrm{s}$ vary from 1.931 to $3.383 \mathrm{~W}$. For the Sanyo PV module the smallest $\operatorname{MAD}(I)$ s vary between 0.143 and $0.228 \mathrm{~A}$. The smallest $\operatorname{MAD}(P)$ s vary between 4.216 and $8.005 \mathrm{~W}$. For the Kyocera PV module, the greatest $\operatorname{MAD}(I) \mathrm{s}$ are contained in the range from 0.272 to $0.669 \mathrm{~A}$. The greatest MAD $(P) \mathrm{s}$ vary between 8.924 and $19.517 \mathrm{~W}$. The greatest $\operatorname{MAD}(I) \mathrm{s}$ for the Sanyo $\mathrm{PV}$ panel vary from 0.366 to $0.478 \mathrm{~A}$. The greatest $\mathrm{MAD}(P) \mathrm{s}$ range from 13.513 to $16.587 \mathrm{~W}$. In Tables 7 and 8 the values of the percentage ratio $\mathrm{MD}(I) / I_{m p, r e f}$ for the analysed panels, calculated considering the $I-V$ curves at a constant cell temperature of $25^{\circ} \mathrm{C}$, are listed.

Table 7. Maximum current differences between the calculated and the issued $I-V$ characteristics of Kyocera KD245GH-4FB2, at temperature $T=25^{\circ} \mathrm{C}$.

\begin{tabular}{|c|c|c|c|c|c|c|}
\hline \multirow{2}{*}{\multicolumn{2}{|c|}{ Parameters at the Maximum Difference Points }} & \multicolumn{5}{|c|}{ Irradiance $\left(\mathrm{W} / \mathrm{m}^{2}\right)$} \\
\hline & & 200 & 400 & 600 & 800 & 1000 \\
\hline \multirow{4}{*}{ Ishaque et al. model } & Voltage (V) & 26.5 & 33.0 & 33.0 & 32.5 & 36.6 \\
\hline & Issued Current (A) & 1.705 & 1.896 & 3.335 & 5.093 & 0.700 \\
\hline & Calculated Current (A) & 1.564 & 2.198 & 3.626 & 5.387 & 0.467 \\
\hline & $\mathrm{MD}(I) / I_{m p, r e f}(\%)$ & -1.713 & 3.670 & 3.536 & 3.572 & -2.831 \\
\hline \multirow{4}{*}{ Gupta et al. model } & Voltage (V) & 32.9 & 34.5 & 35.0 & 34.9 & 35.0 \\
\hline & Issued Current (A) & 0.623 & 0.885 & 1.512 & 2.587 & 3.557 \\
\hline & Calculated Current (A) & 0.732 & 1.396 & 2.231 & 3.527 & 4.434 \\
\hline & $\mathrm{MD}(I) / I_{m p, r e f}(\%)$ & 1.324 & $\underline{6.209}$ & $\underline{8.736}$ & $\underline{11.422}$ & $\underline{10.656}$ \\
\hline \multirow{4}{*}{ Hejri et al. model } & Voltage (V) & 32.0 & 33.0 & 33.0 & 32.5 & 32.5 \\
\hline & Issued Current (A) & 0.948 & 1.896 & 3.335 & 5.093 & 6.596 \\
\hline & Calculated Current (A) & 1.136 & 2.237 & 3.667 & 5.427 & 6.787 \\
\hline & $\operatorname{MD}(I) / I_{m p, r e f}(\%)$ & $\underline{2.284}$ & 4.156 & 4.034 & 4.058 & 2.321 \\
\hline
\end{tabular}

Considering the $I-V$ curves at constant temperature of the Kyocera PV panel, the smallest percentage values of $\mathrm{MD}(I) / I_{m p \text {, ref }}$ vary from $1.324 \%$ to $3.670 \%$ and the greatest are contained in the range from $2.284 \%$ to $11.422 \%$. The smallest percentage values of $\mathrm{MD}(I) / I_{m p, r e f}$ for the Sanyo PV module 
are in the range from $3.383 \%$ to $12.349 \%$, the greatest vary between $4.919 \%$ and $18.035 \%$. Tables 9 and 10 list the values of the percentage ratio $\mathrm{MD}(I) / I_{m p}$,ref calculated for Kyocera KD245GH-4FB2 and Sanyo HIT-240 HDE4 PV panels at a constant solar irradiance of $1000 \mathrm{~W} / \mathrm{m}^{2}$.

Table 8. Maximum current differences between the calculated and the issued $I-V$ characteristics of Sanyo HIT-240 HDE4, at temperature $T=25^{\circ} \mathrm{C}$.

\begin{tabular}{|c|c|c|c|c|c|c|}
\hline \multirow{2}{*}{\multicolumn{2}{|c|}{ Parameters at the Maximum Difference Points }} & \multicolumn{5}{|c|}{ Irradiance $\left(\mathrm{W} / \mathrm{m}^{2}\right)$} \\
\hline & & 200 & 400 & 600 & 800 & 1000 \\
\hline \multirow{4}{*}{ Ishaque et al. model } & Voltage (V) & 38.5 & 39.1 & 39.7 & 39.1 & 39.1 \\
\hline & Issued Current (A) & 0.471 & 1.187 & 1.819 & 3.350 & 4.529 \\
\hline & Calculated Current (A) & 0.804 & 1.897 & 2.712 & 4.130 & 5.103 \\
\hline & $\mathrm{MD}(I) / I_{m p, r e f}(\%)$ & $\underline{4.919}$ & $\underline{10.487}$ & 13.191 & 11.521 & 8.479 \\
\hline \multirow{4}{*}{ Gupta et al. model } & Voltage $(\mathrm{V})$ & 38.3 & 39.8 & 40.2 & 40.9 & 40.6 \\
\hline & Issued Current (A) & 0.514 & 0.900 & 1.514 & 2.016 & 3.233 \\
\hline & Calculated Current (A) & 0.747 & 1.578 & 2.577 & 3.217 & 4.454 \\
\hline & $\mathrm{MD}(I) / I_{m p, r e f}(\%)$ & 3.456 & 10.030 & $\underline{15.687}$ & $\underline{17.740}$ & $\underline{18.035}$ \\
\hline \multirow{4}{*}{ Hejri et al. model } & Voltage (V) & 37.3 & 38.5 & 39.7 & 40.3 & 40.3 \\
\hline & Issued Current (A) & 0.720 & 1.414 & 1.819 & 2.458 & 3.485 \\
\hline & Calculated Current (A) & 0.949 & 1.979 & 2.654 & 3.336 & 4.368 \\
\hline & $\operatorname{MD}(I) / I_{m p, r e f}(\%)$ & 3.383 & 8.360 & 12.349 & 12.969 & 13.043 \\
\hline
\end{tabular}

Table 9. Maximum current differences between the calculated and the issued $I-V$ characteristics of Kyocera KD245GH-4FB2, at irradiance $G=1000 \mathrm{~W} / \mathrm{m}^{2}$.

\begin{tabular}{ccccc}
\hline \multirow{2}{*}{ Parameters at the Maximum Difference Points } & \multicolumn{3}{c}{ Temperature $\left({ }^{\circ} \mathbf{C}\right)$} \\
\cline { 3 - 5 } & & $\mathbf{2 5}$ & $\mathbf{5 0}$ & $\mathbf{7 5}$ \\
\hline \multirow{3}{*}{ Ishaque et al. model } & Voltage $(\mathrm{V})$ & 36.6 & 29.0 & 26.0 \\
& Issued Current (A) & 0.700 & 6.515 & 5.950 \\
& Calculated Current $(\mathrm{A})$ & 0.467 & 6.776 & 6.342 \\
& $\mathrm{MD}(I) / I_{m p, r e f}(\%)$ & -2.831 & $\mathbf{3 . 1 5 9}$ & $\mathbf{4 . 7 6 3}$ \\
\hline \multirow{5}{*}{ Gupta et al. model } & Voltage $(\mathrm{V})$ & 35.0 & 31.3 & 27.9 \\
& Issued Current $(\mathrm{A})$ & 3.557 & 3.905 & 3.662 \\
& Calculated Current $(\mathrm{A})$ & 4.434 & 5.140 & 5.242 \\
& $\mathrm{MD}(I) / I_{m p, r e f}(\%)$ & $\underline{\mathbf{1 0 . 6 5 6}}$ & $\mathbf{1 5 . 0 0 6}$ & 19.210 \\
\hline \multirow{3}{*}{ Hejri et al. model } & Voltage $(\mathrm{V})$ & 32.5 & 32.5 & 29.5 \\
& Issued Current (A) & 6.596 & 1.998 & 1.326 \\
& Calculated Current $(\mathrm{A})$ & 6.787 & 2.849 & 3.008 \\
& $\mathrm{MD}(I) / I_{m p, r e f}(\%)$ & $\mathbf{2 . 3 2 1}$ & 10.340 & $\mathbf{2 0 . 4 3 7}$ \\
\hline
\end{tabular}

Table 10. Maximum current differences between the calculated and the issued $I-V$ characteristics of Sanyo HIT-240 HDE4, at irradiance $G=1000 \mathrm{~W} / \mathrm{m}^{2}$.

\begin{tabular}{ccccc}
\hline \multirow{2}{*}{ Parameters at the Maximum Difference Points } & \multicolumn{3}{c}{ Temperature $\left({ }^{\circ} \mathbf{C}\right)$} \\
\cline { 3 - 5 } & & $\mathbf{2 5}$ & $\mathbf{5 0}$ & $\mathbf{7 5}$ \\
\hline \multirow{4}{*}{ Ishaque et al. model } & Voltage $(\mathrm{V})$ & 39.1 & 37.3 & 37.9 \\
& Issued Current (A) & 4.529 & 3.810 & 0.438 \\
& Calculated Current $(\mathrm{A})$ & 5.103 & 4.192 & 0.165 \\
& $\mathrm{MD}(I) / I_{m p, r e f}(\%)$ & $\mathbf{8 . 4 7 9}$ & $\mathbf{5 . 6 5 7}$ & $\mathbf{- 4 . 0 4 7}$ \\
\hline \multirow{5}{*}{ Gupta et al. model } & Voltage $(\mathrm{V})$ & 40.6 & 38.2 & 35.5 \\
& Issued Current (A) & 3.233 & 2.953 & 3.042 \\
& Calculated Current $(\mathrm{A})$ & 4.454 & 4.195 & 4.248 \\
& $\mathrm{MD}(I) / I_{m p, r e f}(\%)$ & $\underline{\mathbf{1 8 . 0 3 5}}$ & $\underline{\mathbf{1 8 . 3 6 0}}$ & $\mathbf{1 7 . 8 2 9}$ \\
\hline \multirow{3}{*}{ Hejri et al. model } & Voltage $(\mathrm{V})$ & 40.3 & 38.2 & 36.1 \\
& Issued Current (A) & 3.485 & 2.981 & 2.366 \\
& Calculated Current $(\mathrm{A})$ & 4.368 & 3.993 & 3.543 \\
& $\mathrm{MD}(I) / I_{m p, r e f}(\%)$ & 13.043 & 14.948 & 17.386 \\
\hline & & & &
\end{tabular}


The smallest percentage values of $\mathrm{MD}(I) / I_{m p}$,ref for the Kyocera PV module at constant solar irradiance range from $2.321 \%$ to $4.763 \%$; the greatest percentage values of $\mathrm{MD}(I) I_{m p, r e f}$ vary between $10.656 \%$ and $20.437 \%$. For the Sanyo PV panel the smallest percentage values of $\mathrm{MD}(I) / I_{m p, r e f}$ vary from $-4.047 \%$ to $8.479 \%$; the greatest are contained in the range from $17.829 \%$ to $18.360 \%$. Tables $11-14$ show the values of the percentage ratio $\mathrm{MD}(P) / V_{m p, r e f} I_{m p, \text { ref }}$ calculated for the analysed PV modules.

Table 11. Maximum power differences between the calculated and the issued $I-V$ characteristics of Kyocera KD245GH-4FB2, at temperature $T=25^{\circ} \mathrm{C}$.

\begin{tabular}{|c|c|c|c|c|c|c|}
\hline \multirow{2}{*}{\multicolumn{2}{|c|}{ Parameters at the Maximum Difference Points }} & \multicolumn{5}{|c|}{ Irradiance $\left(\mathrm{W} / \mathrm{m}^{2}\right)$} \\
\hline & & 200 & 400 & 600 & 800 & 1000 \\
\hline \multirow{4}{*}{ Ishaque et al. model } & Voltage (V) & 32.5 & 33.0 & 33.0 & 32.5 & 36.6 \\
\hline & Issued Power $(\mathrm{W})$ & 25.34 & 62.55 & 110.06 & 165.51 & 25.62 \\
\hline & Calculated Power (W) & 29.41 & 72.53 & 119.65 & 175.06 & 17.10 \\
\hline & $\operatorname{MD}(P) / V_{m p, r e f} I_{m p, r e f}(\%)$ & 1.660 & 4.064 & 3.912 & 3.893 & -3.475 \\
\hline \multirow{4}{*}{ Gupta et al. model } & Voltage $(\mathrm{V})$ & 32.9 & 34.5 & 35.0 & 34.9 & 35.0 \\
\hline & Issued Power $(\mathrm{W})$ & 20.52 & 30.50 & 52.87 & 90.25 & 124.50 \\
\hline & Calculated Power (W) & 24.10 & 48.09 & 78.01 & 123.04 & 155.20 \\
\hline & $\operatorname{MD}(P) / V_{m p, r e f} I_{m p, r e f}(\%)$ & 1.462 & $\underline{7.176}$ & $\underline{10.253}$ & $\underline{13.368}$ & 12.518 \\
\hline \multirow{4}{*}{ Hejri et al. model } & Voltage $(\mathrm{V})$ & 32.0 & 33.0 & 33.0 & 33.5 & 32.5 \\
\hline & Issued Power $(W)$ & 30.34 & 62.55 & 110.06 & 141.51 & 214.37 \\
\hline & Calculated Power (W) & 36.35 & 73.83 & 121.00 & 152.52 & 220.59 \\
\hline & $\mathrm{MD}(P) / V_{m p, r e f} I_{m p, r e f}(\%)$ & $\underline{2.449}$ & 4.598 & 4.461 & 4.487 & 2.536 \\
\hline
\end{tabular}

Table 12. Maximum power differences between the calculated and the issued $I-V$ characteristics of Sanyo HIT-240 HDE4, at temperature $T=25^{\circ} \mathrm{C}$.

\begin{tabular}{lcccccc}
\hline \multirow{2}{*}{ Parameters at the Maximum Difference Points } & \multicolumn{5}{c}{ Irradiance $\left(\mathbf{W} / \mathbf{m}^{\mathbf{2}}\right)$} \\
\cline { 3 - 7 } & & $\mathbf{2 0 0}$ & $\mathbf{4 0 0}$ & $\mathbf{6 0 0}$ & $\mathbf{8 0 0}$ & $\mathbf{1 0 0 0}$ \\
\hline \multirow{4}{*}{ Ishaque et al. model } & Voltage $(\mathrm{V})$ & 38.5 & 39.1 & 39.7 & 39.1 & 39.7 \\
& Issued Power $(\mathrm{W})$ & 18.13 & 46.44 & 72.26 & 131.07 & 159.62 \\
& Calculated Power $(\mathrm{W})$ & 30.98 & 74.21 & 107.75 & 161.58 & 182.29 \\
& $\mathrm{MD}(P) / V_{m p, r e f} I_{m p, r e f}(\%)$ & $\underline{\mathbf{5 . 3 4 4}}$ & $\underline{\mathbf{1 1 . 5 5 5}}$ & 14.768 & $\mathbf{1 2 . 6 9 7}$ & $\mathbf{9 . 4 3 5}$ \\
\hline \multirow{5}{*}{ Gupta et al. model } & Voltage $(\mathrm{V})$ & 38.3 & 40.2 & 40.8 & 40.9 & 40.9 \\
& Issued Power $(\mathrm{W})$ & 19.69 & 29.77 & 46.50 & 82.44 & 119.63 \\
& Calculated Power $(\mathrm{W})$ & 28.65 & 56.93 & 89.79 & 131.54 & 169.56 \\
& $\mathrm{MD}(P) / V_{m p, r e f} I_{m p, r e f}(\%)$ & 3.727 & 11.299 & $\underline{\mathbf{1 8 . 0 0 9}}$ & $\underline{\mathbf{2 0 . 4 2 9}}$ & $\underline{\mathbf{2 0 . 7 7 7}}$ \\
\hline \multirow{3}{*}{ Hejri et al. model } & Voltage $(\mathrm{V})$ & 37.3 & 39.1 & 39.7 & 40.3 & 40.3 \\
& Issued Power $(\mathrm{W})$ & 26.89 & 46.44 & 72.26 & 99.14 & 140.56 \\
& Calculated Power $(\mathrm{W})$ & 35.43 & 68.43 & 105.46 & 134.55 & 176.15 \\
& $\mathrm{MD}(P) / V_{m p, r e f} I_{m p, r e f}(\%)$ & $\mathbf{3 . 5 5 3}$ & $\mathbf{9 . 1 4 9}$ & $\mathbf{1 3 . 8 1 2}$ & 14.734 & 14.811 \\
\hline
\end{tabular}

For the Kyocera PV panel, the smallest percentage values of $\mathrm{MD}(P) / V_{m p, r e f} I_{m p, \text { ref }}$ at constant cell temperature vary from $1.462 \%$ to $4.064 \%$. The greatest percentage values of $\mathrm{MD}(P) / V_{m p, r e f} I_{m p, r e f}$ are in the range $2.449 \%$ to $13.368 \%$. For the Sanyo PV module, the smallest percentage values of $\mathrm{MD}(P) / V_{m p, r e f} I_{m p, r e f}$ at constant temperature vary from $3.553 \%$ to $13.812 \%$; the greatest range $5.344 \%$ to $20.777 \%$.

Considering the $\operatorname{MD}(P) / V_{m p, r e f} I_{m p, r e f}$ at constant solar irradiance, the smallest percentage values for the Kyocera PV panel range from $2.536 \%$ to $4.151 \%$; the greatest vary between $12.518 \%$ and $20.235 \%$. The smallest percentage values of $\mathrm{MD}(P) / V_{m p, r e f} I_{m p, r e f}$ for the Sanyo PV module are in the range from $-4.319 \%$ to $9.435 \%$; the greatest vary from $17.803 \%$ to $20.777 \%$. Tables 15 and 16 list the percentage ratios of $\operatorname{MAD}(I)$ to the current at the issued $\operatorname{MPP}$ and of $\operatorname{MAD}(P)$ to the rated maximum power. 
The average values of the ratios of $\operatorname{MAD}(I)$ to the current at the issued MPP, and of $\operatorname{MAD}(P)$ to the rated maximum power, calculated for all $I-V$ curves, are indicated in the last column.

Table 13. Maximum power differences between the calculated and the issued $I-V$ characteristics of Kyocera KD245GH-4FB2, at irradiance $G=1000 \mathrm{~W} / \mathrm{m}^{2}$.

\begin{tabular}{ccccc}
\hline \multirow{2}{*}{ Parameters at the Maximum Difference Points } & \multicolumn{3}{c}{ Temperature $\left({ }^{\circ} \mathrm{C}\right)$} \\
\cline { 3 - 5 } & & $\mathbf{2 5}$ & $\mathbf{5 0}$ & $\mathbf{7 5}$ \\
\hline \multirow{4}{*}{ Ishaque et al. model } & Voltage $(\mathrm{V})$ & 36.6 & 29.5 & 26.0 \\
& Issued Power $(\mathrm{W})$ & 25.62 & 178.15 & 154.70 \\
& Calculated Power $(\mathrm{W})$ & 17.10 & 185.74 & 164.88 \\
& $\mathrm{MD}(P) / V_{m p, r e f} I_{m p, r e f}(\%)$ & -3.475 & $\mathbf{3 . 0 9 5}$ & $\mathbf{4 . 1 5 1}$ \\
\hline \multirow{5}{*}{ Gupta et al. model } & Voltage $(\mathrm{V})$ & 35.0 & 31.3 & 27.9 \\
& Issued Power $(\mathrm{W})$ & 124.50 & 122.12 & 102.32 \\
& $\mathrm{Calculated}$ Power $(\mathrm{W})$ & 155.20 & 160.74 & 146.49 \\
& $\mathrm{MD}(P) / V_{m p, r e f} I_{m p, r e f}(\%)$ & $\underline{\mathbf{1 2 . 5 1 8}}$ & $\underline{\mathbf{1 5 . 7 4 7}}$ & 18.009 \\
\hline \multirow{3}{*}{ Hejri et al. model } & Voltage $(\mathrm{V})$ & 32.5 & 32.5 & 29.5 \\
& $\mathrm{Issued}$ Power $(\mathrm{W})$ & 214.37 & 64.94 & 39.12 \\
& $\mathrm{Calculated} \mathrm{Power}(\mathrm{W})$ & 220.59 & 92.60 & 88.74 \\
& $\mathrm{MD}(P) / V_{m p, r e f} I_{m p, r e f}(\%)$ & $\mathbf{2 . 5 3 6}$ & 11.279 & $\mathbf{2 0 . 2 3 5}$ \\
\hline
\end{tabular}

Table 14. Maximum power differences between the calculated and the issued $I-V$ characteristics of Sanyo HIT-240 HDE4, at irradiance $G=1000 \mathrm{~W} / \mathrm{m}^{2}$.

\begin{tabular}{|c|c|c|c|c|}
\hline \multirow{2}{*}{\multicolumn{2}{|c|}{ Parameters at the Maximum Difference Points }} & \multicolumn{3}{|c|}{ Temperature $\left({ }^{\circ} \mathrm{C}\right)$} \\
\hline & & 25 & 50 & 75 \\
\hline \multirow{4}{*}{ Ishaque et al. model } & Voltage (V) & 39.7 & 37.3 & 37.9 \\
\hline & Issued Power $(\mathrm{W})$ & 159.62 & 142.18 & 16.62 \\
\hline & Calculated Power (W) & 182.29 & 156.45 & 6.24 \\
\hline & $\mathrm{MD}(P) / V_{m p, r e f} I_{m p, r e f}(\%)$ & 9.435 & 5.940 & -4.319 \\
\hline \multirow{4}{*}{ Gupta et al. model } & Voltage (V) & 40.9 & 38.2 & 35.5 \\
\hline & Issued Power (W) & 119.63 & 112.78 & 107.85 \\
\hline & Calculated Power (W) & 169.56 & 160.25 & 150.64 \\
\hline & $\mathrm{MD}(P) / V_{m p, r e f} I_{m p, r e f}(\%)$ & $\underline{20.777}$ & $\underline{19.751}$ & $\underline{17.803}$ \\
\hline \multirow{4}{*}{ Hejri et al. model } & Voltage (V) & 40.3 & 38.2 & 36.1 \\
\hline & Issued Power (W) & 140.56 & 113.78 & 85.45 \\
\hline & Calculated Power (W) & 176.15 & 152.40 & 127.97 \\
\hline & $\operatorname{MD}(P) / V_{m p, r e f} I_{m p, r e f}(\%)$ & 39.7 & 16.070 & 17.692 \\
\hline
\end{tabular}

Table 15. Percentage ratio of $\mathrm{MAD}(I)$ to the rated current at the MPP.

\begin{tabular}{|c|c|c|c|c|c|c|c|c|c|}
\hline \multirow{3}{*}{ PV Panel } & \multirow{2}{*}{$\begin{array}{l}I-V \text { Characteristic } \\
\text { Irradiance }\left(\mathrm{W} / \mathrm{m}^{2}\right)\end{array}$} & \multicolumn{8}{|c|}{$\operatorname{MAD}(I) / I_{m p, r e f}(\%)$} \\
\hline & & 200 & 400 & 600 & 800 & 1000 & 1000 & 1000 & Average \\
\hline & Temperature $\left({ }^{\circ} \mathrm{C}\right)$ & 25 & 25 & 25 & 25 & 25 & 50 & 75 & Value \\
\hline \multirow{3}{*}{$\begin{array}{c}\text { Kyocera } \\
\text { KD245GH-4FB2 }\end{array}$} & Ishaque et al. model & $\underline{0.95}$ & 1.32 & 1.24 & 1.06 & 0.72 & 1.03 & 1.51 & 1.12 \\
\hline & Gupta et al. model & $\overline{0.64}$ & 2.11 & 2.89 & 3.63 & 3.30 & 3.83 & 5.20 & 3.09 \\
\hline & Hejri et al. model & 0.83 & 1.52 & 1.48 & 1.54 & 0.81 & 4.11 & $\underline{8.49}$ & 2.68 \\
\hline \multirow{3}{*}{$\begin{array}{l}\text { Sanyo HIT-240 } \\
\text { HDE4 }\end{array}$} & Ishaque et al. model & 2.53 & 4.15 & 4.98 & 4.39 & 3.37 & 2.85 & 2.11 & 3.48 \\
\hline & Gupta et al. model & $\overline{1.18}$ & 3.31 & 5.07 & 5.54 & 5.55 & 5.41 & 5.45 & $\underline{4.50}$ \\
\hline & Hejri et al. model & 1.08 & 2.58 & 3.80 & 4.09 & 4.12 & 5.35 & $\underline{7.06}$ & $\overline{4.01}$ \\
\hline
\end{tabular}


Table 16. Percentage ratio of $\operatorname{MAD}(P)$ to the rated maximum power.

\begin{tabular}{|c|c|c|c|c|c|c|c|c|c|}
\hline \multirow{3}{*}{ PV Panel } & \multirow{2}{*}{$\begin{array}{l}\text { I-V Characteristic } \\
\text { Irradiance }\left(\mathrm{W} / \mathrm{m}^{2}\right)\end{array}$} & \multicolumn{8}{|c|}{$\operatorname{MAD}(P) / V_{m p, r e f} I_{m p, r e f}(\%)$} \\
\hline & & 200 & 400 & 600 & 800 & 1000 & 1000 & 1000 & Ave \\
\hline & Temperature $\left({ }^{\circ} \mathrm{C}\right)$ & 25 & 25 & 25 & 25 & 25 & 50 & 75 & Valu \\
\hline \multirow{3}{*}{$\begin{array}{c}\text { Kyocera } \\
\text { KD245GH-4FB2 }\end{array}$} & Ishaque et al. model & $\underline{0.86}$ & 1.34 & 1.31 & 1.15 & 0.79 & 0.97 & 1.32 & 1.11 \\
\hline & Gupta et al. model & $\overline{0.66}$ & 2.30 & 3.20 & 4.05 & 3.64 & 3.56 & 4.38 & 3.11 \\
\hline & Hejri et al. model & 0.85 & 1.59 & 1.56 & 1.63 & 0.82 & 4.07 & $\underline{7.96}$ & $\underline{2.64}$ \\
\hline \multirow{3}{*}{$\begin{array}{l}\text { Sanyo HIT-240 } \\
\text { HDE4 }\end{array}$} & Ishaque et al. model & $\underline{2.27}$ & 4.12 & 5.09 & 4.45 & 3.33 & 2.59 & 1.75 & 3.37 \\
\hline & Gupta et al. model & $\overline{1.22}$ & 3.58 & 5.61 & 6.20 & 6.20 & 5.62 & 5.27 & $\underline{4.81}$ \\
\hline & Hejri et al. model & 1.08 & 2.74 & 4.09 & 4.44 & 4.47 & 5.49 & $\underline{6.90}$ & $\overline{4.17}$ \\
\hline
\end{tabular}

For the Kyocera PV panel the smallest $\operatorname{MAD}(I)$ s range from $0.64 \%$ to $1.51 \%$ of the current at the MPP; the greatest $\operatorname{MAD}(I)$ s vary from $0.95 \%$ to $8.49 \%$. The smallest MAD $(I)$ s for the Sanyo PV module are in the range $1.08 \%$ to $4.09 \%$ of the current at the MPP; the greatest $\mathrm{MAD}(I) \mathrm{s}$ range from $2.53 \%$ to $7.06 \%$. The smallest $\mathrm{MAD}(P) \mathrm{s}$ range from $0.66 \%$ to $1.34 \%$ of the rated maximum power for the Kyocera PV panel; the greatest MAD $(P)$ s vary from $0.86 \%$ to $7.96 \%$. For the Sanyo PV module the smallest $\operatorname{MAD}(P) \mathrm{s}$ are in the range $1.08 \%$ to $4.44 \%$ of the rated maximum power; the greatest $\operatorname{MAD}(P) \mathrm{s}$ vary from $2.27 \%$ to $6.90 \%$.

\section{Rating of the Usability and Accuracy of the Simplified One-Diode Models}

In order to rate the usability and accuracy of the analysed models, the criterion based on a three-level rating scale described in [60] was adopted. The three-level rating scale takes into consideration the following features:

- $\quad$ the ease of finding the performance data used by the analytical procedure;

- the simplicity of the mathematical tools needed to perform calculations;

- the accuracy achieved in calculating the current and power of the analysed PV modules.

The ease of finding the input data is assumed:

- high, when only tabular data are required;

- $\quad$ medium, when the data have to be extracted by reading the $I-V$ characteristics;

- $\quad l o w$, when the derivative of the $I-V$ curves are required.

The simplicity of the used mathematical tools is considered:

- high, if only simple calculations are necessary;

- medium, if an iterative procedure is used;

- low, when the analytical procedure requires the use of dedicated computational software.

Table 17 lists the average ratios of $\operatorname{MAD}(I)$ to the rated current at the MPP, and of $\operatorname{MAD}(P)$ to the rated maximum power, extracted from Tables 15 and 16.

Table 17. Average ratios of $\operatorname{MAD}(I)$ to the rated current at the $\operatorname{MPP}$ and of $\operatorname{MAD}(P)$ to the rated maximum power.

\begin{tabular}{cccccc}
\hline \multirow{2}{*}{ Model } & \multicolumn{2}{c}{ Average MAD $(I) / I_{m p, r e f}(\%)$} & \multicolumn{2}{c}{ Average MAD(P)/ $V_{m p, r e f} I_{m p, r e f}(\%)$} & Global \\
\cline { 2 - 5 } & $\begin{array}{c}\text { Kyocera } \\
\text { KD245GH-4FB2 }\end{array}$ & $\begin{array}{c}\text { Sanyo HIT-240 } \\
\text { HDE4 }\end{array}$ & $\begin{array}{c}\text { Kyocera } \\
\text { KD245GH-4FB2 }\end{array}$ & $\begin{array}{c}\text { Sanyo HIT-240 } \\
\text { HDE4 }\end{array}$ & Accuracy \\
\hline Ishaque et al. & 1.12 & 3.48 & 1.11 & 3.37 & $\mathbf{2 . 2 7}$ \\
Gupta et al. & 3.09 & 4.50 & 3.11 & 4.81 & $\underline{\mathbf{3 . 8 8}}$ \\
Hejri et al. & 2.68 & 4.01 & 2.64 & 4.17 & 3.38 \\
\hline
\end{tabular}


The global accuracy listed in Table 17, which is calculated averaging the accuracies evaluated for the Kyocera and Sanyo PV panels, varies between $2.27 \%$ and $3.88 \%$. Such range of variation was divided in three equal intervals, which were used to qualitatively describe the accuracy of the analysed models:

- high, for values of the mean difference in the subrange $2.27 \%$ to $2.81 \%$;

- medium, for values of the mean difference in the subrange $2.81 \%$ to $3.34 \%$;

- low, for values of the mean difference in the subrange $3.34 \%$ to $3.88 \%$.

Table 18 lists the rating of the ease of finding data, simplicity of mathematical tools, and accuracy in calculating the current and power, based on the three-level rating scale previously described.

Table 18. Usability and accuracy ratings of the analysed one-diode models.

\begin{tabular}{cccc}
\hline Model & Ease of Data Finding & Mathematical Simplicity & Current and Power Accuracy \\
\hline Ishaque et al. & High & Medium & High \\
Gupta et al. & High & High & Low \\
Hejri et al. & Low & Low & Low \\
\hline
\end{tabular}

Excepting the Hejri et al. model, the models require data that are easy to be found. The Gupta et al. model achieves a small accuracy and presents the greatest mathematical difficulties. The Ishaque et al. model, which is very accurate and has a medium degree of mathematical difficulty, may be considered the best option among the two-diode models.

In order to assess the suitability of adopting two-diode models instead of one-diode models, a comparison with the performances of the best known diode-based models was carried out considering the $I-V$ characteristics of the same PV panels. Table 19 lists the usability and accuracy ratings of the one-diode models ranked in $[60,62]$ along with the ones of the two-diode models analysed in the present paper. To make a consistent comparison, the accuracy was rated on the basis of the smallest and the greatest mean differences calculated for all the analysed models. According to such minimum and maximum values, the following accuracy subranges were defined:

- $\quad$ high, for values of the mean difference in the subrange $0.53 \%$ to $1.91 \%$;

- medium, for values of the mean difference in the subrange $1.91 \%$ to $3.30 \%$;

- low, for values of the mean difference in the subrange $3.30 \%$ to $4.68 \%$.

It can be observed that the analysed two-diode models reach values of the accuracy comparable with the precision of the simplified one-diode models. Such result is not surprising because, as it was previously pointed out, only a part of the seven parameters of the two-diode models are obtained from the equations that describe the relevant proprieties of the $I-V$ curves. Actually, the Hejri et al. model is a five-parameter model because it arbitrarily sets the values of $a_{1}$ and $a_{2}$. The Ishaque et al. model is a four-parameter model because it also fix $I_{02}=I_{01}$. The Gupta et al. model is a tree-parameter model because the values of $a_{1}, a_{2}, R_{s}$ and $R_{s h}$ are not obtained from calculations. As a consequence, it is quite logical that such incomplete seven-parameter models do not surpass the accuracy of the one-diode models.

No model achieves the highest ratings for all the considered features. For this reason the choice of the best model requires a wise compromise between usability and accuracy. The Orioli et al. model, the Townsend n.2 model, the Saloux et al. model and the Mahmoud et al. $n .2$ model have the best global rating. The Orioli et al. model, which reaches a high precision, presents some mathematical difficulties; conversely, the parameters of the Townsend n.2 model, the Saloux et al. model and the Mahmoud et al. n.2 model can be easily calculated but these models are less precise. 
Table 19. Usability and accuracy ratings of the analysed one-diode based models.

\begin{tabular}{|c|c|c|c|c|}
\hline & Model & $\begin{array}{l}\text { Ease of Data } \\
\text { Finding }\end{array}$ & $\begin{array}{l}\text { Mathematical } \\
\text { Simplicity }\end{array}$ & $\begin{array}{c}\text { Current and } \\
\text { Power Accuracy }\end{array}$ \\
\hline \multirow{9}{*}{ One-diode } & Hadj Arab et al. & Low & High & Medium \\
\hline & De Soto et al. & Medium & Low & Medium \\
\hline & Sera et al. & Low & Medium & Medium \\
\hline & Villalva et al. & High & Medium & Medium \\
\hline & Lo Brano et al. & Low & Medium & High \\
\hline & Seddaoui et al. & Low & High & Medium \\
\hline & Siddique et al. & High & Medium & Medium \\
\hline & Yetayew et al. & Medium & Low & Medium \\
\hline & Orioli et al. & High & Medium & High \\
\hline \multirow{9}{*}{$\begin{array}{l}\text { Simplified } \\
\text { one-diode }\end{array}$} & Townsend n.1 & High & Low & Medium \\
\hline & Townsend n.2 & High & High & Medium \\
\hline & Duffie et al. & Medium & High & Low \\
\hline & Xiao et al. & High & Medium & Low \\
\hline & Ulapane et al. & High & Medium & Medium \\
\hline & Saloux et al. & High & High & Medium \\
\hline & Mahmoud et al. n.1 & High & Low & Low \\
\hline & Averbukh et al. & High & Low & Low \\
\hline & Mahmoud et al. n.2 & High & High & Medium \\
\hline \multirow{3}{*}{ Two-diode } & Ishaque et al. & High & Medium & Medium \\
\hline & Gupta et al. & High & High & Low \\
\hline & Hejri et al. & Low & Low & Low \\
\hline
\end{tabular}

\section{Conclusions}

In order to rate the usability of the two-diode models for PV cells and panels, the analytical procedures to evaluate the model parameters and the hypotheses, which were adopted to simplify calculations, were described in detail. Using the data extracted from the datasheets issued by the manufactures of two different types of PV modules, the $I-V$ curves at constant cell temperature and solar irradiance were calculated by means of the analysed models. In order to test the model accuracies, the calculated $I-V$ curves were compared with the issued $I-V$ characteristics. The maximum difference and the mean absolute difference between the calculated values of current and the numerous values of current extracted from the issued $I-V$ characteristics were considered; also the maximum difference and the mean absolute difference for the generated power were evaluated.

The achieved accuracy obviously depends on the used model and the considered $I-V$ curve. For the most effective two-diode equivalent circuits, the calculated current differences averagely vary between $0.64 \%$ and $1.51 \%$ of the current at the MPP, for the poly-crystalline Kyocera KD245GH-4FB2 PV panel. The values of the power difference averagely range from $0.66 \%$ to $1.34 \%$ of the rated maximum power. For the Sanyo HIT-240 HDE4 PV module smaller accuracies were generally observed. The current differences averagely vary from $1.08 \%$ to $4.09 \%$ of the current at the MPP. The power accuracies averagely range from $1.08 \%$ and $4.44 \%$ of the rated maximum power. The accuracies of the less effective models averagely reach $8.49 \%$ of the current at the MMP and $7.96 \%$ of the rated maximum power for the Kyocera PV panel, whereas average differences of $7.06 \%$ of the current at the MMP and of $6.90 \%$ of the rated maximum power were observed for the Sanyo PV module.

It is not a trivial matter to identify the most usable and accurate model because no model reaches the highest ratings for all the features considered by the adopted criterion. Among the previously analysed models, the Ishaque et al. model is the most accurate and has a medium degree of mathematical difficulty. If the model comparison is extended to the one-diode based models ranked in $[60,62]$, the best ratings among the simplified one-diode models are given to the Townsend $n .2$ model, the Saloux et al. model and the Mahmoud et al. n.2 model, which present the same degree of ease of data finding, mathematical simplicity and current and power accuracy; the Orioli et al. model 
reaches the best rating among the five-parameter models. The analysed two-diode models do not confirm their supposed capability to yield very accurate results. The lack of effectiveness is probably due to the fact that the proposed analytical procedures arbitrarily fix some of the seven parameters of the two-diode model with the consequence of wasting the opportunities given by the presence of a wider number of model parameters.

Author Contributions: Aldo Orioli and Alessandra Di Gangi conceived and performed the criterion; Vincenzo Franzitta and Aldo Orioli carried out the analysis between the characteristics of the PV modules and the calculated current-voltage curves; Aldo Orioli and Alessandra Di Gangi wrote the paper.

Conflicts of Interest: The authors declare no conflict of interest.

\section{Appendix A.}

In this appendix the equations used by the various two-diode models to describe the physical properties of PV panels are listed along with the analytical procedures adopted to get the explicit or implicit expressions necessary to calculate the equivalent model parameters.

\section{Appendix A.1. Chan and Phang Model}

The following information is used:

(1) shape factor $a_{1}=1$;

(2) shape factor $a_{2}=2$;

(3) short circuit point $\left(I=I_{s c, r e f} ; V=0\right)$;

(4) open circuit point $\left(I=0 ; V=V_{o c, r e f}\right)$;

(5) $\operatorname{MPP}\left(I=I_{m p, r e f} ; V=V_{m p, r e f}\right)$;

(6) derivative of current at the short circuit point $\left(\partial I / \partial V=-1 / R_{\text {sho }}\right.$ at $\left.I=I_{s c, r e f} ; V=0\right)$;

(7) derivative of current at the open circuit point $\left(\partial I / \partial V=-1 / R_{s o}\right.$ at $\left.I=0 ; V=V_{o c, r e f}\right)$;

that permits to write the following equations:

$$
\begin{aligned}
& I_{s c, \text { ref }}=I_{L, \text { ref }}-I_{01, \text { ref }}\left(e^{\frac{I_{s c, r e f} R_{s}}{n T_{r e f}}}-1\right)-I_{02, \text { ref }}\left(e^{\frac{I_{s c, r e f} R_{s}}{2 n T_{r e f}}}-1\right)-\frac{I_{s c, r e f} R_{s}}{R_{s h}} \\
& 0=I_{L, \text { ref }}-I_{01, \text { ref }}\left(e^{\frac{V_{o c, r e f}}{n T_{\text {ref }}}}-1\right)-I_{02, \text { ref }}\left(e^{\frac{V_{o c, r e f}}{2 n T_{r e f}}}-1\right)-\frac{V_{o c, r e f}}{R_{s h}} \\
& I_{m p, r e f}=I_{L, r e f}-I_{01, \text { ref }}\left(e^{\frac{V_{m p, r e f}+I_{m p, r e f} R_{s}}{n T_{\text {ref }}}}-1\right)-I_{02, \text { ref }}\left(e^{\frac{V_{m p, r e}+I_{m p, r e f} R_{s}}{2 n T_{r e f}}}-1\right)-\frac{V_{m p, r e f}+I_{m p, r e f} R_{s}}{R_{s h}}
\end{aligned}
$$

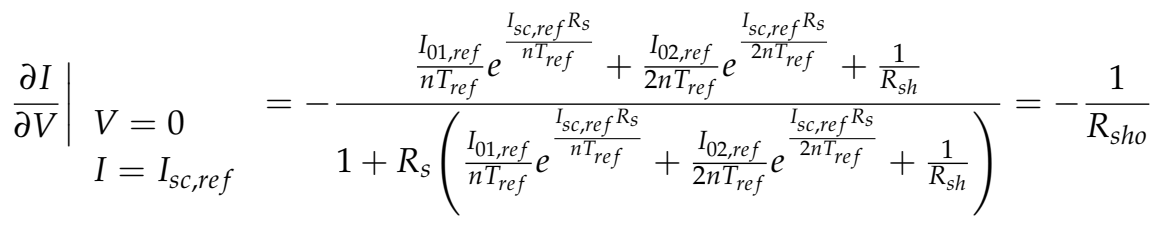

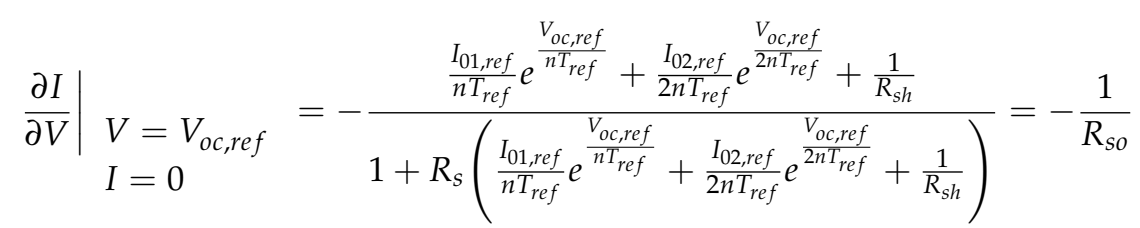

in which $n=N_{c s} k / q$. Assuming the following hypotheses, the equations can be approximated in order to simplify the evaluation of the model parameters: 


$$
\begin{gathered}
e^{\frac{V_{o c, r e f}}{n T_{r e f}}}>>e^{\frac{I_{s c, r e f} R_{s}}{n T_{r e f}}}, \quad e^{\frac{V_{o c, r e f}}{2 n T_{r e f}}}>>e^{\frac{I_{s c, r e f} R_{s}}{2 n T_{r e f}}}, \quad R_{s h}>>R_{s}, \quad R_{\text {sho }}>>R_{s} \\
\frac{I_{01, r e f}}{n T_{r e f}} e^{\frac{I_{s c, r e f} R_{s}}{n T_{r e f}}}<<\frac{1}{R_{\text {sho }}}, \quad \frac{I_{02, r e f}}{2 n T_{\text {ref }}} e^{\frac{I_{s c, r e f} R_{s}}{2 n T_{r e f}}}<<\frac{1}{R_{s h o}}, \quad I_{s c, r e f} R_{s} \quad<<V_{o c, r e f}
\end{gathered}
$$

Using $I_{L, r e f}$ from Equation (A2) and assuming the hypotheses in Equations (A6) and (A7), Equations (A1)-(A5) can be rewritten as:

$$
\begin{gathered}
I_{01, r e f} e^{\frac{V_{o c, r e f}}{n T_{r e f}}}+I_{02, r e f} e^{\frac{V_{o c, r e f}}{2 n T_{r e f}}}-I_{s c, r e f}+\frac{V_{o c, r e f}}{R_{s h}}=0 \\
I_{01, r e f}\left(e^{\frac{V_{o c, r e f}}{n T_{r e f}}}-e^{\frac{V_{m p, r e f}+I_{m p, r e f} R_{s}}{n T_{r e f}}}\right)+I_{02, r e f}\left(e^{\frac{V_{o c, r e f}}{2 n T_{r e f}}}-e^{\frac{V_{m p, r e f}+I_{m p, r e f} R_{s}}{2 n T_{r e f}}}\right)+\frac{V_{o c, r e f}-V_{m p, r e f}}{R_{s h}}-I_{m p, r e f}=0 \\
R_{s h}=R_{s h o} \\
\left(R_{s o}-R_{s}\right)\left(\frac{I_{01, r e f}}{n T_{r e f}} e^{\frac{V_{o c, r e f}}{n T_{r e f}}}+\frac{I_{02, r e f}}{2 n T_{r e f}} e^{\frac{V_{o c, r e f}}{2 n T_{r e f}}}\right)-1=0
\end{gathered}
$$

Extracting $I_{01, \text { ref }}$ and $I_{02, \text { ref }}$ from Equations (A8) and (A9), and using Equation (A10), the following expression, which only contains the unknown series resistance, can be obtained from Equation (A11):

$$
\begin{aligned}
& I_{s c, r e f}-I_{m p, r e f}-\frac{V_{m p, r e f}}{R_{s h o}}-\left(\frac{V_{o c, r e f}}{R_{s h o}}-I_{s c, r e f}+\frac{2 n T_{r e f}}{R_{s o}-R_{s}}\right) e^{\frac{V_{m p, r e f}-V_{o c, r e f}}{n T_{r e f}}} e^{\frac{I_{m p, r e f} R_{s}}{n T_{r e f}}}+ \\
& -2\left(I_{s c, r e f}-\frac{V_{o c, r e f}}{R_{s h o}}-\frac{n T_{r e f}}{R_{s o}-R_{s}}\right) e^{\frac{V_{m p, r e} V_{o c, r e f}}{2 n T_{r e f}}} e^{\frac{I_{m p, r e f} R_{s}}{2 n T_{r e f}}}=0
\end{aligned}
$$

In order to get the solution of Equation (A12), the exponential terms containing parameter $R_{S}$ can be substituted with their respective power series:

$$
\begin{aligned}
& e^{\frac{I_{m p, r e f} R_{s}}{n T_{r e f}}}=1+\frac{I_{m p, r e f} R_{s}}{n T_{r e f}}+\frac{1}{2 !}\left(\frac{I_{m p, r e f} R_{s}}{n T_{r e f}}\right)^{2}+\frac{1}{3 !}\left(\frac{I_{m p, r e f} R_{s}}{n T_{r e f}}\right)^{3}+\ldots \\
& e^{\frac{I_{m p, r e f} R_{s}}{2 n T_{r e f}}}=1+\frac{I_{m p, r e f} R_{s}}{2 n T_{r e f}}+\frac{1}{2 !}\left(\frac{I_{m p, r e f} R_{s}}{2 n T_{r e f}}\right)^{2}+\frac{1}{3 !}\left(\frac{I_{m p, r e f} R_{s}}{2 n T_{r e f}}\right)^{3}+\cdots
\end{aligned}
$$

Using the first two terms of Equations (A13) and (A14), Equation (A12) can be approximated with the following quadratic form:

$$
a_{2} R_{s}^{2}+a_{1} R_{s}+a_{0}=0
$$

whereas, if the first three terms of Equations (A13) and (A14) are used, a cubic form can be obtained:

$$
b_{3} R_{s}^{3}+b_{2} R_{s}^{2}+b_{1} R_{s}+b_{0}=0
$$

Both Equations (A15) and (A16) can be easily solved by means of ordinary mathematical methods because the involved coefficients $a$ and $b$ only contain known quantities. Diode currents $I_{01, \text { ref }}$ and $I_{02, \text { ref }}$ can be calculated with the following equations obtained by solving Equations (A8) and (A11):

$$
\begin{aligned}
& I_{01, r e f}=\left(\frac{V_{o c, r e f}}{R_{s h o}}-I_{s c, r e f}+\frac{2 n T_{r e f}}{R_{s o}-R_{s}}\right) e^{-\frac{V_{o c, r e f}}{n T_{r e f}}} \\
& I_{02, r e f}=\left(I_{s c, r e f}-\frac{V_{o c, r e f}}{R_{s h o}}-\frac{n T_{r e f}}{R_{s o}-R_{s}}\right) e^{-\frac{V_{o c, r e f}}{2 n T_{r e f}}}
\end{aligned}
$$


The shunt resistance can be calculated with the following equation, obtained from Equation (A4):

$$
R_{s h}=\left(\frac{1}{R_{s h o}-R_{s}}-\frac{I_{01, r e f} R_{s}}{n T_{r e f}} e^{\frac{I_{m p, r e f} R_{s}}{n T_{r e f}}}-\frac{I_{02, r e f} R_{s}}{2 n T_{r e f}} e^{\frac{I_{m p, r e f} R_{s}}{2 n T_{r e f}}}\right)^{-1}
$$

whereas photocurrent $I_{L, \text { ref }}$ is calculated from Equations (A2):

$$
I_{L, \text { ref }}=I_{01, \text { ref }}\left(e^{\frac{V_{o c, r e f}}{n T_{r e f}}}-1\right)+I_{02, \text { ref }}\left(e^{\frac{V_{o c, \text { ref }}}{2 n T_{\text {ref }}}}-1\right)+\frac{V_{o c, \text { ref }}}{R_{s h}}
$$

Appendix A.2. Enebish, Agchbayar, Dorjkhand, Baatar and Ylemj Model

The model uses the following information:

(1) shape factor $a_{1}=1$;

(2) shape factor $a_{2}=2$;

(3) short circuit point $\left(I=I_{s c, r e f} ; V=0\right)$;

(4) open circuit point $\left(I=0 ; V=V_{o c, \text { ref }}\right)$;

(5) derivative of current at the short circuit point $\left(\partial I / \partial V=-1 / R_{\text {sho }}\right.$ at $\left.I=I_{s c, \text { ref }} ; V=0\right)$;

(6) derivative of current at the open circuit point $\left(\partial I / \partial V=-1 / R_{s o}\right.$ at $\left.I=0 ; V=V_{o c, r e f}\right)$;

(7) derivative of power at the MPP $\left(\partial(V I) / \partial V=0 ; V=V_{m p, r e f}\right)$.

The first six pieces of information are represented by Equations (A1), (A2), (A4) and (A5); the information regarding the derivative of power at the MPP is described by the following equation:

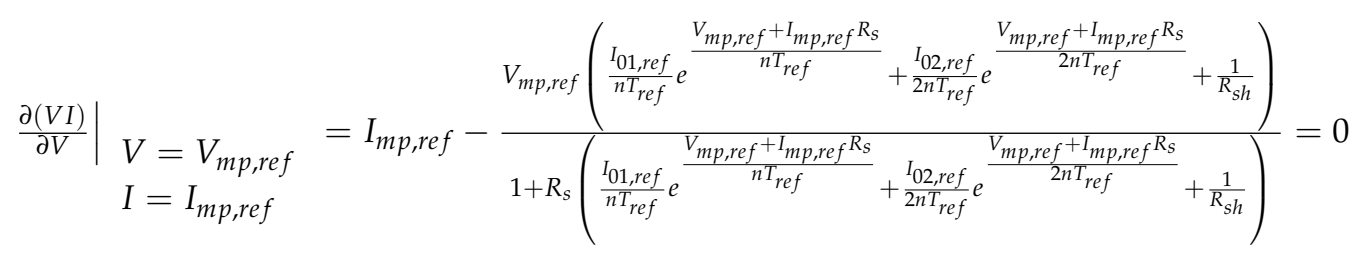

in which $n=N_{c s} k / q$. The equation system is solved with the Newton-Raphson technique. Because the convergence of the procedure strongly depends on the initial values of $I_{L, \text { ref }}, I_{01, \text { ref }}, I_{02, \text { ref }}, R_{S}$, and $R_{s h}$, the following relations are used to begin the evaluation of the model parameters:

$$
\begin{gathered}
I_{L, r e f}=I_{s c, r e f} \\
I_{01, r e f}=\frac{I_{L, r e f}}{2} e^{-\frac{V_{o c, r e f}}{n T_{r e f}}} \\
I_{02, r e f}=\frac{I_{L, r e f}}{2} e^{-\frac{V_{o c, r e f}}{2 n T_{r e f}}} \\
R_{s}=\frac{12 P_{0}}{I_{s c, r e f}^{2}}-\frac{12 P_{1}}{I_{s c, r e f}^{3}}+\frac{6 V_{o c, r e f}}{I_{s c, r e f}}+3 R_{s o} \\
\frac{1}{R_{s h}}=\frac{1}{V_{o c, r e f}^{2}}\left(10 P_{0}-\frac{12 P_{1}}{I_{s c, r e f}}+I_{s c, r e f}^{2} R_{s o}\right)-\frac{4 I_{s c, r e f}}{V_{o c, r e f}}
\end{gathered}
$$

in which $P_{0}$ and $P_{1}$ are the areas under the $I-V$ and the $V I-V$ curves at the SRC, respectively.

Appendix A.3. Hovinen Model

The following information is used: 
(1) shape factor $a_{1}=1$;

(2) shape factor $a_{2}=2$;

(3) short circuit point $\left(I=I_{s c, r e f} ; V=0\right)$;

(4) open circuit point $\left(I=0 ; V=V_{o c, r e f}\right)$;

(5) $\operatorname{MPP}\left(I=I_{m p, r e f} ; V=V_{m p, r e f}\right)$;

(6) derivative of current at the short circuit point $\left(\partial I / \partial V=-1 / R_{\text {sho }}\right.$ at $\left.I=I_{s c, \text { ref }} ; V=0\right)$;

(7) derivative of power at the MPP $\left(\partial P / \partial V=0 ; V=V_{m p, r e f}\right)$.

Using the following notation:

$$
\begin{gathered}
A=e^{\frac{V_{o c, r e f}}{n T_{r e f}}}, \quad B=e^{\frac{V_{o c, r e f}}{2 n T_{r e f}}}, \quad C=e^{\frac{I_{s c, r e f} R_{s}}{n T_{r e f}}}, \quad D=e^{\frac{I_{s c, r e f} R_{s}}{2 n T_{r e f}}} \\
E=e^{\frac{V_{m p, r e f}+I_{m p, r e f} R_{s}}{n T_{r e f}}}, \quad G=e^{\frac{V_{m p, r e f}+I_{m p, r e f} R_{s}}{2 n T_{r e f}}}
\end{gathered}
$$

in which $n=N_{c s} k / q$, Equations (A1)-(A4) and (A21), which represent the used information, can be synthetically rewritten as:

$$
\begin{aligned}
& I_{s c, r e f}=I_{L, r e f}-I_{01, r e f}(C-1)-I_{02, r e f}(D-1)-\frac{I_{s c, r e f} R_{s}}{R_{s h}} \\
& 0=I_{L, r e f}-I_{01, r e f}(A-1)-I_{02, r e f}(B-1)-\frac{V_{o c, r e f}}{R_{s h}} \\
& I_{m p, r e f}=I_{L, r e f}-I_{01, r e f}(E-1)-I_{02, \text { ref }}(G-1)-\frac{V_{m p, r e f}+I_{m p, r e f} R_{s}}{R_{s h}}
\end{aligned}
$$

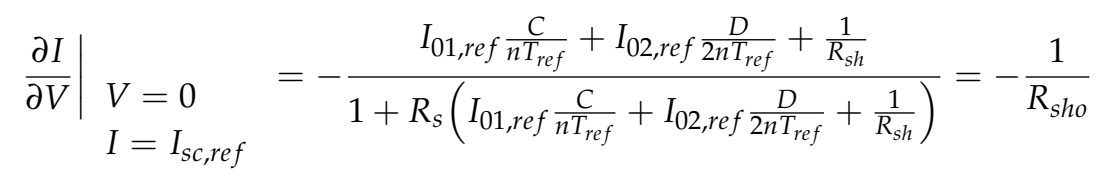

$$
\begin{aligned}
& \left.\frac{\partial(V I)}{\partial V}\right|_{\substack{V=V_{m p, r e f} \\
I=I_{m p, r e f}}}=I_{m p, r e f}-\frac{V_{m p, r e f}\left(I_{01, r e f} \frac{E}{n T_{r e f}}+I_{02, r e f} \frac{G}{2 n T_{r e f}}+\frac{1}{R_{s h}}\right)}{1+R_{s}\left(I_{01, r e f} \frac{E}{n T_{r e f}}+I_{02, r e f} \frac{G}{2 n T_{r e f}}+\frac{1}{R_{s h}}\right)}=0
\end{aligned}
$$

Equations (A29) and (A31) can be solved in order to find the following expressions for diode currents $I_{01, \text { ref }}$ and $I_{02, r e f}$ :

$$
\begin{gathered}
I_{01, \text { ref }} \frac{\delta I_{s c, r e f}-\frac{1}{R_{s h o}-R_{s}}\left[\beta\left(V_{m p, r e f}+I_{m p, r e f} R_{s}-V_{o c, r e f}\right)+\delta\left(V_{o c, r e f}-I_{s c, \text { ref }} R_{s}\right)\right]-\beta I_{m p, r e f}}{\gamma \beta-\alpha \delta} \\
I_{02, \text { ref }}=\frac{1}{\beta}\left(\frac{V_{o c, r e f}-I_{s c, r e f} R_{s}}{R_{s h o}-R_{s}} I_{s c, \text { ref }}-\alpha I_{01, r e f}\right)
\end{gathered}
$$

in which it is:

$$
\begin{gathered}
\alpha=\left(1+\frac{V_{o c, r e f}-I_{s c, r e f} R_{s}}{n T_{r e f}}\right) C-A \\
\beta=\left(1+\frac{V_{o c, r e f}-I_{s c, r e f} R_{s}}{2 n T_{r e f}}\right) D-B \\
\gamma=E-A-C \frac{V_{m p, r e f}+I_{m p, r e f} R_{s}-V_{o c, r e f}}{n T_{r e f}}
\end{gathered}
$$




$$
\delta=G-B-D \frac{V_{m p, r e f}+I_{m p, r e f} R_{s}-V_{o c, r e f}}{2 n T_{r e f}}
$$

From Equation (A32) the following relation can be extracted:

$$
\frac{1}{R_{s h}}=\frac{1}{R_{\text {sho }}-R_{s}}-I_{01, r e f} \frac{C}{n T_{r e f}}+I_{02, r e f} \frac{D}{2 n T_{r e f}}
$$

Using Equations (A30) and (A40), photocurrent $I_{L, r e f}$ can be calculated with the following equation:

$$
I_{L, \text { ref }}=I_{01, \text { ref }}\left(A-1-\frac{V_{o c, r e f}}{n T_{r e f}} C\right)+I_{02, \text { ref }}\left(B-1-\frac{V_{o c, r e f}}{n T_{r e f}} D\right)+\frac{V_{o c, r e f}}{R_{s h o}-R_{s}}
$$

In order to calculate $R_{s}$, which is the only unknown parameter present in Equations (A34)-(A36) and (A40), Equation (A31) can be rewritten in the following form:

$$
1+\left(R_{s}+\frac{V_{m p, r e f}}{I_{m p, r e f}}\right)\left(I_{01, r e f} \frac{E}{n T_{r e f}}+I_{02, r e f} \frac{G}{2 n T_{r e f}}+\frac{1}{R_{s h}}\right)=0
$$

Parameters $I_{01, \text { ref }}, I_{02, \text { ref }}, R_{s h}$, and $I_{L, \text { ref }}$ can be calculated by means the following iterative procedure:

(1) an initial value of $R_{S}$ is assumed;

(2) $I_{01, \text { ref }}$ is calculated by Equation (A34);

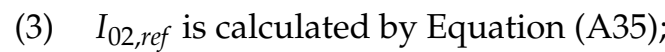

(4) $R_{\text {sh }}$ is calculated by Equation (A40);

(5) $I_{L, r e f}$ is calculated by Equation (A41);

(6) the iterative procedure is concluded if Equation (A42) is verified within a fixed accuracy; otherwise, a new value of $R_{S}$ is assumed and the procedure is repeated.

\section{Appendix A.4. Ishaque, Salam and Taheri Model}

The model uses the following information:

(1) shape factor $a_{1}=1$;

(2) shape factor $a_{2} \geq 1.2$;

(3) diode current $I_{02}=I_{01}=I_{0}$;

(4) short circuit point $\left(I=I_{s c, r e f} ; V=0\right)$;

(5) open circuit point $\left(I=0 ; V=V_{o c, r e f}\right)$;

(6) $\operatorname{MPP}\left(I=I_{m p, r e f} ; V=V_{m p, r e f}\right)$;

(7) maximum power $\left(P=P_{m p, r e f}\right)$.

Due to the first three pieces of information, Equation (1) is simplified in the following form:

$$
I=I_{L}-I_{0}\left(e^{\frac{V+I R_{S}}{n T}}+e^{\frac{V+I R_{s}}{(p-1) n T}}-2\right)-\frac{V+I R_{S}}{R_{s h}}
$$

in which $n=N_{c s} k / q$ and $p=a_{1}+a_{2}$. Assuming the hypotheses:

$$
e^{\frac{I_{s c, r e f} R_{s}}{n T_{r e f}}} \approx 1, \quad e^{\frac{I_{s c \text { ref }} R_{s}}{(p-1) n T_{r e f}}} \approx 1, \quad \frac{I_{s c, r e f} R_{s}}{R_{s h}} \approx 0
$$

the photocurrent at the SRC can be calculated with following equation derived from the short circuit condition:

$$
I_{s c, r e f}=I_{L, r e f}
$$


Because in the MPP it is:

$$
P_{m p, r e f}=V_{m p, r e f}\left[I_{L, r e f}-I_{0, r e f}\left(e^{\frac{V_{m p, r e f}+I_{m p, r e f} R_{s}}{n T}}+e^{\frac{V_{m p, r e f}+I_{m p, r e f} R_{s}}{(p-1) n T}}-2\right)-\frac{V_{m p, r e f}+I_{m p, r e f} R_{s}}{R_{s h}}\right]
$$

where $P_{m p, r e f}$ is the measured peak power, or the value issued on datasheet, resistance $R_{s h}$ can be calculated by means of the following equation:

$$
R_{s h}=\frac{V_{m p, r e f}+I_{m p, r e f} R_{s}}{I_{L, \text { ref }}-I_{0, r e f}\left(e^{\frac{V_{m p, r e f}+I_{s c, \text { ref }} R_{s}}{n T}}+e^{\frac{V_{m p, r e f}+I_{s c, \text { ref }} R_{s}}{(p-1) n T}}-2\right)-\frac{P_{m p, r e f}}{V_{m p, r e f}}}
$$

To consider the effects of solar irradiance $G$ and silicon temperature $T$, the photocurrent is evaluated with the following form proposed by Townsend [3]:

$$
I_{L}(G, T)=\left[I_{s c, r e f}+\mu_{I, s c}\left(T-T_{r e f}\right)\right] \frac{G}{G_{r e f}}
$$

whereas, for the diode reverse current, the following equation is used:

$$
I_{0}(T)=\frac{I_{s c, r e f}+\mu_{I, s c}\left(T-T_{r e f}\right)}{e^{\frac{V_{o c, r e f}+\mu_{V, o c}\left(T-T_{r e f}\right)}{\left(a_{1}+a_{2}\right) n T / p}}-1}
$$

In order to calculate the model parameters, an iterative procedure, similar to the procedure described by Villalva et al. [9], is used. The idea is to match the calculated peak power and the experimental peak power, which may be extracted from the manufacturer's datasheets, by iteratively increasing the value of $R_{s}$ while simultaneously calculating the value of $R_{s h}$. The following sequence of steps is adopted:

(1) fixed values of $a_{1}$ and $a_{2}$ are set to calculate $n$ and $p$;

(2) an initial values of $R_{s h}$ is assumed;

(3) an initial values of $R_{S}$ is assumed;

(4) $I_{L}$ is calculated by Equation (A48);

(5) $I_{0}$ is calculated by Equation (A49);

(6) $R_{s h}$ is calculated by Equation (A47):

(7) Equation (A43) is used in order to find the MPP and calculate the maximum power;

(8) the calculated maximum power is compared with the issued value of $P_{m p, r e f}$;

(9) the iterative procedure is concluded if the comparison is satisfied within a fixed accuracy; otherwise, a new value of $R_{S}$ is assumed and steps $4,5,6,7$ and 8 are repeated.

The following initial values of the series and shunt resistances are suggested:

$$
R_{s}=0, \quad R_{s h}=\frac{V_{m p, r e f}}{I_{s c, r e f}-I_{m p, r e f}}-\frac{V_{o c, r e f}-V_{m p, r e f}}{I_{m p, r e f}}
$$

The model uses Equations (A48) and (A49) to calculate the $I-V$ characteristics for conditions different from the SRC. 
Appendix A.5. Gupta, Tiwari, Fozdar and Chandna Model

The following information is used:

(1) shape factor $a_{1}=1$;

(2) shape factor $a_{2}=1$;

(3) shunt resistance $R_{s h}=\infty$;

(4) fixed value of series resistance $R_{s}$;

(5) short circuit point $\left(I=I_{s c, r e f} ; V=0\right)$;

(6) $\operatorname{MPP}\left(I=I_{m p, r e f ;} V=V_{m p, r e f}\right)$.

Due to the first three pieces of information and ignoring the last term of Equation (1), which corresponds to set $R_{s h}=\infty$, Gupta et al. transformed the two-diode equation in the following form:

$$
I=I_{L}-I_{01}\left(e^{\frac{V}{K_{2} V_{o c, r e f}}}-1\right)-K_{1} I_{01}\left(e^{\frac{V}{K_{2} V_{o c, r e f}}}-1\right)
$$

in which:

$$
I_{02}=K_{1} I_{01}, \quad \frac{\left(V+I R_{s}\right)}{n_{1} T}=\frac{\left(V+I R_{s}\right)}{n_{2} T}=\frac{V}{K_{2} V_{o c, r e f}}
$$

Considering that in short circuit point at the SRC, the exponential terms of Equation (A51) are equal to one, it is:

$$
I_{L, r e f}=I_{s c, r e f}
$$

Equation (A51) becomes:

$$
I=I_{s c, r e f}\left[1-K_{3}\left(e^{\frac{V}{K_{2} V_{o c, r e f}}}-1\right)\left(1+K_{1}\right)\right]
$$

in which $I_{01}=K_{3} I_{s c, \text { ref }}$. Coefficient $K_{3}$ can be extracted from Equation (A54) considering the piece of information that refers to the MPP at the SRC:

$$
K_{3}=\frac{1-\frac{I_{m p, r e f}}{I_{s c, \text { ref }}}}{\left(e^{V_{m p, r e f} V_{o c, r e f}}-1\right)\left(1+K_{1}\right)}
$$

Under the open circuit conditions, Equation (A54) becomes:

$$
0=I_{s c, r e f}\left[1-K_{3}\left(e^{\frac{1}{K_{2}}}-1\right)\left(1+K_{1}\right)\right]
$$

If Equation (A47) is substituted in Equation (A56), the following expression for $K_{2}$ can be obtained:

$$
K_{2}=\frac{\frac{V_{m p, r e f}}{V_{o c, \text { ref }}}-1}{\ln \left(1-\frac{I_{m p, r e f}}{I_{s c, \text { ref }}}\right)}
$$

For parameter $K_{1}$ it is empirically assumed that:

$$
K_{1}=\frac{T^{2 / 5}}{3.77}
$$

The evaluation of the model parameters requires the following simple steps: 
(1) coefficient $K_{1}$ is calculated by Equation (59);

(2) coefficient $K_{2}$ is calculated by Equation (58);

(3) coefficient $K_{3}$ is calculated by Equation (56).

The effects of the cell temperature and solar radiation were included by adding the following corrections to the values of $I$ and $V$ in Equation (A54):

$$
\begin{gathered}
\Delta I=\mu_{I, s c} \frac{G}{G_{r e f}}\left(T-T_{r e f}\right)+\left(\frac{G}{G_{r e f}}-1\right) I_{s c, r e f} \\
\Delta V=\mu_{V, o c}\left(T-T_{r e f}\right)-R_{s} \Delta I
\end{gathered}
$$

In order to use Equation (A60), a value of $R_{s}$ is needed; unfortunately, no information was provided by the authors about the way to fix the value of the series resistance.

\section{Appendix A.6. Hejri, Mokhtari, Azizian, Ghandhari and Söder Model}

The model uses the following information:

(1) shape factor $a_{1}=1$;

(2) shape factor $a_{2}=2$;

(3) short circuit point $\left(I=I_{s c, r e f} ; V=0\right)$;

(4) open circuit point $\left(I=0 ; V=V_{o c, r e f}\right)$;

(5) $\operatorname{MPP}\left(I=I_{m p, r e f ;} V=V_{m p, r e f}\right)$;

(6) derivative of current at the short circuit point $\left(\partial I / \partial V=-1 / R_{\text {sho }}\right.$ at $\left.I=I_{s c, \text { ref }} ; V=0\right)$;

(7) derivative of power at the MPP $\left(\partial P / \partial V=0 ; V=V_{m p, r e f}\right)$.

The used information is described by Equations (A1)-(A4) and (A21). From Equation (A2), which refers to the open circuit condition, the following expression can be derived:

$$
I_{L, r e f}=I_{01, r e f}\left(e^{\frac{V_{o c, r e f}}{n T_{r e f}}}-1\right)+I_{02, r e f}\left(e^{\frac{V_{o c, r e f}}{2 n T_{r e f}}}-1\right)+\frac{V_{o c, r e f}}{R_{s h}}
$$

in which $n=N_{c s} k / q$. Equation (A61) can be substituted in Equations (A1) and (A3), which represent the short circuit point and the MPP conditions, respectively:

$$
\begin{aligned}
& I_{s c, r e f}=I_{01, r e f}\left(e^{\frac{V_{o c, r e f}}{n T_{r e f}}}-e^{\frac{I_{s c, r e f} R_{s}}{n T_{r e f}}}\right)+I_{02, r e f}\left(e^{\frac{V_{o c, r e f}}{2 n T_{r e f}}}-e^{\frac{I_{s c, r e f} R_{s}}{2 n T_{r e f}}}\right)+\frac{V_{o c, r e f}-I_{s c, r e f} R_{s}}{R_{s h}} \\
& I_{m p, r e f}=I_{01, r e f}\left(e^{\frac{V_{o c, r e f}}{n T_{r e f}}}-e^{\frac{V_{m p, r e f}+I_{m p, r e f} R_{s}}{n T_{r e f}}}\right)+I_{02, r e f}\left(e^{\frac{V_{o c, r e f}}{2 n T_{r e f}}}-e^{\frac{V_{m p, r e f}+I_{m p, r e f} R_{s}}{2 n T_{r e f}}}\right)+ \\
& +\frac{V_{o c, r e f}-V_{m p, r e f}+I_{m p, r e f} R_{s}}{R_{s h}}
\end{aligned}
$$

Assuming the following hypotheses:

$$
e^{\frac{V_{o c, \text { ref }}}{n I_{\text {ref }}}}>>e^{\frac{I_{S c, r e f} R_{S}}{n I_{r e f}}}, \quad e^{\frac{V_{o c, r e f}}{2 n I_{r e f}}}>>e^{\frac{I_{S c, \text { ref }} R_{S}}{2 n I_{r e f}}}
$$

Equations (A62) and (A63) can be rewritten as:

$$
I_{01, r e f}\left(e^{\frac{V_{o c, r e f}}{n T_{r e f}}}-e^{\frac{I_{s c, r e f} R_{s}}{n T_{r e f}}}\right)+I_{02, r e f}\left(e^{\frac{V_{o c, r e f}}{2 n T_{r e f}}}-e^{\frac{I_{s c, r e f} R_{s}}{2 n T_{r e f}}}\right)=I_{s c, r e f}-\frac{V_{o c, r e f}-I_{s c, r e f} R_{s}}{R_{s h}}
$$




$$
\begin{aligned}
& I_{01, r e f}\left(e^{\frac{V_{c c, r e f}}{n T_{r e f}}}-e^{\frac{V_{m p, r e f}+I_{m p, r e f} R_{s}}{n T_{r e f}}}\right)+I_{02, r e f}\left(e^{\frac{V_{o c, r e f}}{2 n T_{r e f}}}-e^{\frac{V_{m p, r e f}+I_{m p, r e f} R_{s}}{2 n T_{r e f}}}\right)=I_{m p, r e f}\left(1+\frac{R_{s}}{R_{s h}}\right)+ \\
& -\frac{V_{o c, \text { ref }}-V_{m p, r e f}}{R_{s h}}
\end{aligned}
$$

and solved with respect to the unknown variables $I_{01, \text { ref }}$ and $I_{02, \text { ref }}$ :

$$
\begin{aligned}
& I_{01, r e f}=\frac{M e^{-\frac{V_{o c, r e f}}{2 n T_{r e f}}}-N e^{-\frac{V_{m p, r e f}+I_{m p, r e f} R_{s}}{2 n T_{r e f}}}}{e^{\frac{V_{c c, r e f}}{2 n T_{r e f}}}-e^{\frac{V_{m p, r e f}+I_{m p, r e f} R_{s}}{2 n T_{r e f}}}} \\
& I_{02, r e f}=\frac{M e^{-\frac{V_{o c, r e f}}{n T_{\text {ref }}}}-N e^{-\frac{V_{m p, r e f}+I_{m p, r e f} R_{s}}{n T_{\text {ref }}}}}{e^{-\frac{V_{o c, \text { ref }}}{2 n T_{\text {ref }}}}-e^{-\frac{V_{m p, r e f}+I_{m p, r e} R_{s}}{2 n T_{r e f}}}}
\end{aligned}
$$

where it is:

$$
\begin{gathered}
M=\left(1+\frac{R_{s}}{R_{s h}}\right) I_{s c, r e f}-\frac{V_{o c, r e f}}{R_{s h}} \\
N=\left(1+\frac{R_{s}}{R_{s h}}\right)\left(I_{s c, r e f}-I_{m p, r e f}\right)-\frac{V_{m p, r e f}}{R_{s h}}
\end{gathered}
$$

Equation (A4), which refers to the derivative of the current at the short circuit point, can be rewritten in the following form:

$$
\left(R_{\text {sho }}-R_{s}\right)\left(\frac{I_{01, r e f}}{n T_{r e f}} e^{\frac{I_{s c, r e f} R_{s}}{n T_{r e f}}}+\frac{I_{02, r e f}}{2 n T_{r e f}} e^{\frac{I_{s c, r e f} R_{s}}{2 n T_{r e f}}}+\frac{1}{R_{s h}}\right)-1=0
$$

Because it is usually:

$$
\frac{I_{01, \text { ref }}}{n T_{\text {ref }}} e^{\frac{I_{\text {sc,ref } R_{s}}}{n T_{\text {ref }}}} \quad<<\frac{1}{R_{\text {sho }}} \quad \frac{I_{02, \text { ref }}}{2 n T_{\text {ref }}}<<\frac{1}{R_{\text {sho }}}, \quad R_{s}<<R_{\text {sh }}
$$

from Equation (A71) one can conclude that $R_{s h o} \approx R_{s h}$ and Equation (A71) can be used in the form:

$$
\left(R_{\text {sh }}-R_{s}\right)\left(\frac{I_{01, r e f}}{n T_{\text {ref }}} e^{\frac{I_{s c, r e f} R_{s}}{n T_{\text {ref }}}}+\frac{I_{02, \text { ref }}}{2 n T_{\text {ref }}} e^{\frac{I_{s c, r e f} R_{s}}{2 n T_{r e f}}}+\frac{1}{R_{\text {sh }}}\right)-1=0
$$

that avoids the graphical extraction of parameter $R_{\text {sho }}$ from the experimental $I-V$ curve of the analysed PV panel. Because the derivative of the current is:

$$
\frac{\partial I}{\partial V}=-\left(1+R_{s} \frac{\partial I}{\partial V}\right)\left(\frac{I_{01}}{n T} e^{\frac{V+I R_{S}}{n T}}+\frac{I_{02}}{2 n T} e^{\frac{V+I R_{S}}{2 n T}}+\frac{1}{R_{s h}}\right)
$$

from the condition regarding the maximum power:

$$
\left.\frac{\partial(P)}{\partial V}\right|_{\substack{V=V_{m p, r e f} \\ I=I_{m p . r e f}}}=\left.\frac{\partial(V I)}{\partial V}\right|_{\substack{V=V_{m p, r e f} \\ I=I_{m p, r e f}}}=I_{m p, r e f}+\left.V_{m p, r e f} \frac{\partial I}{\partial V}\right|_{\substack{V=V_{m p, r e f} \\ I=I_{m p, r e f}}}=0
$$

it can be extracted the following form:

$$
\begin{aligned}
& \left.\frac{\partial I}{\partial V}\right|_{V=V_{m p, r e f}}=-\frac{I_{m p, r e f}}{V_{m p, r e f}} \\
& I=I_{m p, r e f}
\end{aligned}
$$


that can be used in Equation (A74) to write the following equation:

$$
\frac{I_{m p, r e f}}{V_{m p, r e f}}=\left(1-R_{s} \frac{I_{m p, r e f}}{V_{m p, r e f}}\right)\left(\frac{I_{01}}{n T} e^{\frac{V_{m p, r e f}+I_{m p, r e f} R_{s}}{n T}}+\frac{I_{02}}{2 n T} e^{\frac{V_{m p, r e f}+I_{m p, r e f} R_{s}}{2 n T}}+\frac{1}{R_{s h}}\right)
$$

Model parameters $I_{01, r e f}, I_{02, \text { ref }}$ and $I_{L, \text { ref }}$ are expressed the equations by Equations (A67), (A68) and $\mathrm{A}(61)$ in which unknown resistances $R_{S}$ and $R_{s h}$ are present. To calculate the series and shunt resistances, Equations (A73) and (A77) can be solved with the Newton-Raphson method. Unfortunately, because of the very small terms $I_{01, \text { ref }}$ and $I_{02, \text { ref }}$, the Newton-Raphson method may not converge for some PV modules. To overcome such a difficulty, Equations (A67) and (A68) are used to eliminate $I_{01, \text { ref }}$ and $I_{02, \text { ref }}$ in Equations (A73) and (A77). To consider the dependence on the temperature and irradiance the following relations are used:

$$
\begin{gathered}
I_{L}(G, T)=\left[I_{L, r e f}+\mu_{I, s c}\left(T-T_{r e f}\right)\right] \frac{G}{G_{r e f}} \\
I_{01}(T)=I_{01, r e f}\left(\frac{T}{T_{r e f}}\right)^{3} e^{\frac{q \varepsilon_{G} G}{k}\left(\frac{1}{T_{r e f}}-\frac{1}{T}\right)} \\
I_{02}(T)=I_{02, r e f}\left(\frac{T}{T_{r e f}}\right)^{\frac{5}{2}} e^{\frac{q \varepsilon_{G} G}{2 k}\left(\frac{1}{T_{r e f}}-\frac{1}{T}\right)} \\
R_{s}(G)=R_{s, r e f} \\
R_{s h}(G)=R_{s h, r e f} \frac{G_{r e f}}{G}
\end{gathered}
$$

where $R_{s, r e f}$ and $R_{s h, r e f}$ are the series and shunt resistances, evaluated by solving Equations (A73) and (A77) at the SRC, and $\varepsilon_{G}$ is the bandgap energy of the material that for silicon cells is calculated with the following equation:

$$
\varepsilon_{G}=1.121\left[1-0.0002677\left(T-T_{r e f}\right)\right]
$$

\section{References}

1. Kennerud, K.L. Analysis of performance degradation in CdS solar cells. IEEE Trans. Aerosp. Electron. Syst. 1969, 5, 912-917. [CrossRef]

2. Phang, J.C.H.; Chan, D.S.H.; Phillips, J.R. Accurate analytical method for the extraction of solar cell model parameters. Electron. Lett. 1984, 20, 406-408. [CrossRef]

3. Townsend, T.U. A Method for Estimating the Long-Term Performance of Direct-Coupled Photovoltaic Systems. Master's Thesis, Mechanical Engineering, University of Wisconsin-Madison, Madison, WI, USA, 1989.

4. Ikegami, T.; Maezono, T.; Nakanishi, F.; Yamagata, Y.; Ebihara, K. Estimation of equivalent circuit parameters of PV module and its application to optimal operation of PV system. Sol. Energy Mater. Sol. Cells 2001, 67, 389-395. [CrossRef]

5. De Blas, M.A.; Torres, J.L.; Prieto, E.; Garcia, A. Selecting a suitable model for characterizing photovoltaic devices. Renew. Energy 2002, 25, 371-380. [CrossRef]

6. Hadj Arab, A.; Chenlo, F; Benghanem, M. Loss-of-load probability of photovoltaic water pumping systems. Sol. Energy 2004, 76, 713-723. [CrossRef]

7. De Soto, W.; Klein, S.A.; Beckman, W.A. Improvement and validation of a model for photovoltaic array performance. Sol. Energy 2006, 80, 78-88. [CrossRef]

8. Sera, D.; Teodorescu, R.; Rodriguez, P. PV panel model based on datasheet values. In Proceedings of the 2007 IEEE International Symposium on Industrial Electronics (ISIE 2007), Vigo, Spain, 4-7 June 2007; pp. 2392-2396. 
9. Villalva, M.G.; Gazoli, J.R.; Filho, E.R. Comprehensive approach to modeling and simulation of photovoltaic arrays. IEEE Trans. Power Electron. 2009, 24, 1198-1208. [CrossRef]

10. Coelho, R.F.; Cancer, F.; Martins, D.C. A proposed photovoltaic module and array mathematical modeling destined to simulation. IEEE Int. Symp. Ind. Electron. (ISIE) 2009, 1624-1629.

11. Lo Brano, V.; Orioli, A.; Ciulla, G.; Di Gangi, A. An improved five-parameter model for photovoltaic modules. Sol. Energy Mater. Sol. Cells 2010, 94, 1358-1370. [CrossRef]

12. Kim, W.; Choi, W. A novel parameter extraction method for the one-diode solar cell model. Sol. Energy 2010, 84, 1008-1019. [CrossRef]

13. Farivar, G.; Asaei, B. Photovoltaic module single diode model parameters extraction based on manufacturer datasheet parameters. In Proceedings of the IEEE International Conference on Power and Energy (PECon), Kuala Lumpur, Malaysia, 29 November-1 December 2010; pp. 929-934.

14. Carrero, C.; Ramírez, D.; Rodríguez, J.; Platero, C.A. Accurate and fast convergence method for parameter estimation of PV generators based on three main points of the I-V curve. Renew. Energy 2011, 36, 2972-2977. [CrossRef]

15. Chatterjee, A.; Keyhani, A.; Kapoor, D. Identification of photovoltaic source models. IEEE Trans. Energy Convers. 2011, 26, 883-889. [CrossRef]

16. Farret, F.A.; Lenz, J.M.; Trapp, J.G. New methodology to determinate photovoltaic parameters of solar panels. In Proceedings of the Brazilian Power Electronics Conference (COBEP), Natal, Brazil, 11-15 September 2011; pp. 275-279.

17. Seddaoui, N.; Rahmani, L.; Kessal, A.; Chauder, A. Parameters extraction of photovoltaic module at reference and real conditions. In Proceedings of the 46th International Universities' Power Engineering Conference (UPEC), Soest, Germany, 5-8 September 2011; pp. 1-6.

18. Katsanevakis, M. Modelling the photovoltaic module. In Proceedings of the IEEE International Symposium on Industrial Electronics (ISIE), Gdansk, Poland, 27-30 June 2011; pp. 1414-1419.

19. Lo Brano, V.; Orioli, A.; Ciulla, G. On the experimental validation of an improved five-parameter model for silicon photovoltaic modules. Sol. Energy Mater. Sol. Cells 2012, 105, 27-39. [CrossRef]

20. Lineykin, S.; Averbukh, M.; Kuperman, A. A five-parameter model of photovoltaic cell based on STC data and dimensioneless. In Proceedings of the IEEE 27th Convention of Electrical \& Electronics Engineers in Israel (IEEEI), Eilat, Israel, 14-17 November 2012; pp. 1-5.

21. Can, H.; Ickilli, D.; Parlak, K.S. A new numerical solution approach for the real-time modeling of photovoltaic panels. In Proceedings of the Asia-Pacific Power and Energy Engineering Conference (APPEEC), Shanghai, China, 27-29 March 2012; pp. 1-4.

22. Ahmad, M.; Talukder, A.; Tanni, M.A. Estimation of important parameters of photovoltaic modules from manufacturer's datasheet. In Proceedings of the International Conference on Informatics, Electronics \& Vision (ICIEV), Dhaka, Bangladesh, 18-19 May 2012; pp. 571-576.

23. Mahmoud, S.A.; Mohamed, H.N. Novel modeling approach for photovoltaic arrays. In Proceedings of the IEEE 55th International Midwest Symposium on Circuits and Systems (MWSCAS), Boise, ID, USA, 5-8 August 2012; pp. 790-793.

24. Sangsawang, V.; Chaitusanel, S. Modeling of photovoltaic module from commercial specification in datasheet. In Proceedings of the 9th International Conference on Electrical Engineering/Electronics, Computer, Telecommunications and Information Technology (ECTI-CON), Phetchaburi, Thailand, 16-18 May 2012; pp. 1-4.

25. Tian, H.; Mancilla-David, F.; Ellis, K.; Muljadi, E.; Jenkins, P. A cell-to-module-to-array detailed model for photovoltaic panels. Sol. Energy 2012, 86, 2695-2706. [CrossRef]

26. Orioli, A.; Di Gangi, A. A procedure to calculate the five-parameter model of crystalline silicon photovoltaic modules on the basis of the tabular performance data. Appl. Energy 2013, 102, 1160-1177. [CrossRef]

27. Islam, M.A.; Merabet, A.; Beguenane, R.; Ibrahim, H. Modeling solar photovoltaic cell and simulated performance analysis of a 250W PV module. In Proceedings of the IEEE Electrical Power \& Energy Conference (EPEC), Halifax, NS, Canada, 21-23 August 2013; pp. 1-6.

28. Jena, D.; Ramana, V.V. Simple and accurate method of modelling photovoltaic module: A different approach. In Proceedings of the International Conference on Green Computing, Communication and Conservation of Energy (ICGCE), Chennai, India, 12-14 December 2013; pp. 465-469. 
29. Mahmoud, Y.; Xiao, W.; Zeineldin, H.H. A simple approach to modeling and simulation of photovoltaic modules. IEEE Trans. Sustain. Energy 2012, 3, 185-186. [CrossRef]

30. Mahmoud, Y.; Xiao, W.; Zeineldin, H.H. A parameterization approach for enhancing PV model accuracy. IEEE Trans. Ind. Electron. 2013, 60, 5708-5716. [CrossRef]

31. Siddique, H.A.B.; Xu, P.W.; De Doncker, R. Parameter extraction algorithm for one-diode model of PV panels based on datasheet values. In Proceedings of the International Conference on Clean Electrical Power (ICCEP), Alghero, Italy, 11-13 June 2013; pp. 7-13.

32. Siddiqui, M.U.; Arif, A.F.M.; Bilton, A.M.; Dubowsky, S.; Elshafei, M. An improved electric circuit model for photovoltaic modules based on sensitivity analysis. Sol. Energy 2013, 90, 29-42. [CrossRef]

33. Tian, H.; Mancilla-David, F.; Muljadi, E.; Stoffel, T.; Andreas, A. Model validation of photovoltaic systems. In Proceedings of the IEEE Green Technologies Conference, Denver, CO, USA, 4-5 April 2013; pp. $93-97$.

34. Yetayew, T.T.; Jyothsna, T.R. Improved single-diode modeling approach for photovoltaic modules using data sheet. In Proceedings of the Annual IEEE India Conference (INDICON), Mumbai, India, 13-15 December 2013; pp. 1-6.

35. Bai, J.; Liu, S.; Hao, Y.; Zhang, Z.; Jiang, M.; Zhang, Y. Development of a new compound method to extract the five parameters of PV modules. Energy Convers. Manag. 2014, 79, 294-303. [CrossRef]

36. Cubas, J.; Pindado, S.; Victoria, M. On the analytical approach for modeling photovoltaic systems behaviour. J. Power Sour. 2014, 247, 467-474. [CrossRef]

37. Lineykin, S.; Averbukh, M.; Kuperman, A. An improved approach to extract the single-diode equivalent circuit parameters of a photovoltaic cell/panel. Renew. Sustain. Energy Rev. 2014, 30, 282-289. [CrossRef]

38. Ma, T.; Yang, H.; Lu, L. Development of a model to simulate the performance characteristics of crystalline silicon photovoltaic modules/strings/arrays. Sol. Energy 2014, 100, 31-41. [CrossRef]

39. Xu, Y.; Kong, X.; Zeng, Y.; Tao, S.; Xiao, X. A modeling method for photovoltaic cells using explicit equations and optimization algorithm. Electr. Power Energy Syst. 2014, 59, 23-28. [CrossRef]

40. Chan, D.S.H.; Phang, J.C.H. Analytical methods for the extraction of solar-cell single- and double-diode model parameters from I-V characteristics. IEEE Trans. Electron Devices 1987, 34, 286-293. [CrossRef]

41. Enebish, N.; Agchbayar, D.; Dorjkhand, S.; Baatar, D.; Ylemj, I. Numerical analysis of solar cell current-voltage characteristics. Sol. Energy Mater. Sol. Cells 1993, 29, 201-208. [CrossRef]

42. Hovinen, A. Fitting of the solar cell IV-curve to the two diode model. Phys. Scr. 1994, T54, 175-176. [CrossRef]

43. Ishaque, K.; Salam, Z.; Taheri, H. Simple, fast and accurate two-diode model for photovoltaic modules. Sol. Energy Mater. Sol. Cells 2011, 95, 586-594. [CrossRef]

44. Gupta, S.; Tiwari, H.; Fozdar, M.; Chandna, V. Development of a two diode model for photovoltaic modules suitable for use in simulation studies. In Proceedings of the Asia-Pacific Power and Energy Engineering Conference (APPEEC), Shanghai, China, 27-29 March 2012; pp. 1-4.

45. Hejri, M.; Mokhtari, H.; Azizian, M.R.; Ghandhari, M.; Söder, L. On the parameter extraction of a five-parameter double-diode model of photovoltaic cells and modules. IEEE J. Photovolt. 2014, 4, 915-923. [CrossRef]

46. Jervase, J.A.; Bourdoucen, H.; Al-Lawati, A. Solar cell parameter extraction using genetic algorithms. Meas. Sci. Technol. 2001, 12, 1922-1925. [CrossRef]

47. Jain, A.; Kapoor, A. Exact analytical solutions of the parameters of real solar cells using Lambert W-function. Sol. Energy Mater. Sol. Cells 2004, 81, 269-277. [CrossRef]

48. Ortiz-Conde, A.; García Sanchez, F.J.; Muci, J. New method to extract the model parameters of solar cells from the explicit analytic solutions of their illuminated I-V characteristics. Sol. Energy Mater. Sol. Cells 2006, 90, 352-361. [CrossRef]

49. Mekki, H.; Mellit, A.; Salhi, H.; Khaled, B. Modeling and simulation of photovoltaic panel based on artificial neural networks and VHDL-language. In Proceedings of the 14th IEEE International Conference on Electronics, Circuits and Systems, ICECS, Marrakech, Morocco, 11-14 December 2007; pp. 58-61.

50. Moldovan, N.; Picos, R.; Garcia-Moreno, E. Parameter extraction of a solar cell compact model using genetic algorithms. In Proceedings of the Spanish Conference on Electron Devices, CDE, Santiago De Compostela, Spain, 11-13 February 2009; pp. 379-382.

51. Zagrouba, M.; Sellami, A.; Bouaïcha, M.; Ksouri, M. Identification of PV solar cells and modules parameters using the genetic algorithms: Application to maximum power extraction. Sol. Energy 2010, 84, 860-866. [CrossRef] 
52. Sandrolini, L.; Artioli, M.; Reggiani, U. Numerical method for the extraction of photovoltaic module double-diode model parameters through cluster analysis. Appl. Energy 2010, 87, 442-451. [CrossRef]

53. Ishaque, K.; Salam, Z.; Taheri, H.; Shamsudin, A. A critical evaluation of EA computational methods for photovoltaic cell parameter extraction based on two-diode. Sol. Energy 2011, 85, 1768-1779. [CrossRef]

54. Ishaque, K.; Salam, Z. An improved modelling method to determine the model parameters of photovoltaic (PV) modules using differential evolution (DE). Sol. Energy 2011, 85, 2349-2359. [CrossRef]

55. Askarzadeh, A.; Rezazadeh, A. Parameter identification for solar cell models using harmony search-based algorithms. Sol. Energy 2012, 84, 3241-3249. [CrossRef]

56. Toledo, F.J.; Blanes, J.M.; Garrigós, A.; Martínez, J.A. Analytical resolution of the electrical four-parameters model of a photovoltaic module using small perturbation around the operating point. Renew. Energy 2012, 43, 83-89. [CrossRef]

57. Lun, S.; Du, C.; Yang, G.; Wang, S.; Guo, T.; Sang, J.; Li, J. An explicit approximate I-V characteristic model of a solar cell based on padé approximants. Sol. Energy 2013, 92, 147-159. [CrossRef]

58. Laudani, A.; Riganti Fulginei, F.; Salvini, A. High performing extraction procedure for the one-diode model of a photovoltaic panel from experimental I-V curves by using reduced forms. Sol. Energy 2014, 103, 316-326. [CrossRef]

59. Laudani, A.; Riganti Fulginei, F.; Salvini, A. Identification of the one-diode model for photovoltaic modules from datasheet values. Sol. Energy 2014, 108, 432-446. [CrossRef]

60. Orioli, A.; Di Gangi, A. A criterion for rating the usability and accuracy of the one-diode models for photovoltaic modules. Energies 2016, 9, 427. [CrossRef]

61. Markvart, T.; Costañer, L. Solar Cells. Materials, Manufacture and Operation; Elsevier: Oxford, UK, 2005.

62. Franzitta, V.; Orioli, A.; Di Gangi, A. Assessment of the usability and accuracy of the simplified one-diode models for photovoltaic modules. Energies 2016, 9, 1019. [CrossRef]

(C) 2017 by the authors. Licensee MDPI, Basel, Switzerland. This article is an open access article distributed under the terms and conditions of the Creative Commons Attribution (CC BY) license (http:/ / creativecommons.org/licenses/by/4.0/). 